Article

\title{
Critical Factors on the Capital Structure of Public-Private Partnership Projects: A Sustainability Perspective
}

\author{
Jing Du ${ }^{1}\left(\mathbb{D}\right.$, Hongyue $\mathrm{Wu}^{1, *}$ and Xianbo Zhao ${ }^{2}$ \\ 1 Department of Construction and Real Estate, School of Civil Engineering, Southeast University, \\ Nanjing 210096, China; cathy_djnj@seu.edu.cn \\ 2 School of Engineering and Technology, Central Queensland University, Sydney 2000, Australia; \\ b.zhao@cqu.edu.au \\ * Correspondence: HongyueWu_HW@outlook.com; Tel.: +86-151-5068-6090
}

Received: 25 April 2018; Accepted: 13 June 2018; Published: 18 June 2018

\begin{abstract}
Scientific capital structure is the key to guarantee sufficient funds and achievement of objectives of Public-Private Partnership (PPP) projects, while inappropriate capital structure has caused the failure of many projects. Meanwhile, sustainability is an important concept that should be concerned during the life cycle of PPP projects. Therefore, this study aimed to: (1) identify the critical factors influencing the capital structure of PPP projects from a sustainability perspective; and (2) analyze the relationships between the factors and the capital structure based on qualitative comparative analysis (QCA). This study identified seven critical factors influencing the capital structure of PPP projects. Moreover, the non-economic indicators should be concerned as well as the economic indicators. Thus, proper capital structure not only provides ample funds but also promotes the long-term healthy operation of projects and creates positive effects on the industry, region and society. Furthermore, the findings indicated that benefit, external situation, cost, ability of private sector and government support were the top critical factors. In addition, although risk did not show great importance, it had close relationship with other factors, which means risk should be concerned comprehensively. This study enriches the theoretical research about the capital structure of PPP projects and offers a new idea about the integration of sustainability and PPP projects. In addition, it supports the reasonable selection of capital structure in practice and promotes the practical application of sustainability on PPP projects.
\end{abstract}

Keywords: Public-Private Partnership (PPP); sustainability; capital structure; critical factors

\section{Introduction}

Public-Private Partnership (PPP) is a long-time cooperative relationship between the government and private company [1], which has become an important way of infrastructure construction and public service providence [2,3]. As the supervisor of the projects, the public sector cares about the total benefits of PPP projects, including economic, social and environmental aspects, which are in accordance with the sustainability, while the private sector pays more attention to the profits of company through finishing the construction, financing, operation and other tasks according to the contract as the implementor of the projects. The capital structure of a PPP project includes the source and structure of equity and debt funds, equity-debt ratio, etc., which determine the sufficiency and stability of funds [4]. In practice, many PPP projects suffer from the difficulties of unreasonable capital structure. The main reason why Wuhan Metro Line 8 project was examined by China's Ministry of Finance is that its debt is in the name of equity and the irrational rate of return [5]. Moreover, 
with the increase of investment in Hangzhou Bay Sea-Crossing Bridge, the private sector suffered high pressure of huge funding gap and finally quit [6]. Additionally, Taiwan high-speed railway project faced the high debt ratio caused by the shortage of capital funds, thus the revenues cannot cover the repayments [7]. Meanwhile, Channel Tunnel also had huge financial burdens due to the increase of financing costs and insufficient revenues that cannot repay the debts [8]. Hungary M1-M15 road was nationalized because of huge financial gap caused by the shortage of stable funds [9]. To sum up, unreasonable capital structure cannot guarantee ample funds of a project, which impacts the benefits of private and public sectors and even leads to the failure of a project. Therefore, investigating the critical factors on capital structure of PPP projects plays an important role in achieving proper capital structure and promoting the success of PPP projects.

At the same time, the core concept of sustainability is expanded from "meeting the needs of modern society without affecting future development" [10] to 3E-3P framework, which includes economy, environment, ethics, people, profit and planet [11]. United Nations set 17 goals, many of which share the same scope of PPP projects such as infrastructure, sustainable city and community [12]. Moreover, United Nations Economic Commission for Europe proposed 27 criteria for PPP mode based on sustainable development to deeply combine PPP projects with sustainability [13]. However, sustainability has not been widely applied, where funds problem is highlighted. During the determination of capital structure in PPP projects, the lack of sustainability causes the partners to only care about the short-term economic indicators but omit the long-term impacts on society and the environment, which leads to high costs and insufficient funds at the operation stage of PPP projects [14]. Thus, analyzing the sustainability of the critical factors can help each participant to consider the life-cycle funds and social and environmental impacts of PPP projects and to build more scientific and reliable capital structure that can better satisfy the practical needs.

This study aimed to identify and analyze the critical factors influencing the capital structure of PPP projects from a sustainability perspective and investigate the relationship between factors and the capital structure based on Qualitative Comparative Analysis (QCA). The literature review indicated that recent studies cared more about quantitative models and economic indicators of the capital structure rather than systematic analysis of critical factors and their impacts on long-term healthy operation of PPP projects. A literature analysis was conducted to identify the critical factors. After that, QCA was applied to investigate the relationship between the seven critical factors and capital structure of PPP projects clearly based on 15 PPP projects. Finally, combined the literature and result of QCA, the importance of these factors was discussed. The findings not only enrich the theoretical research of the capital structure in PPP projects, but also provide reference to scientific and reasonable capital structure of PPP projects in practice. Moreover, the study promotes the application of sustainability in PPP projects to facilitate the long-term healthy development of PPP projects, industry, region and the whole society.

\section{Literature Review}

\subsection{Sustainability and Its Application in PPP Projects}

\subsubsection{Concept of Sustainability}

Sustainability is originated from the Brundtland Report, which concentrates on environmental protection and economic development [10]. Studies offer rich explanations of sustainability. Daly [15] indicated that sustainable development of capital concentrated on the multi-level relationship of capitals and the maximum of sustainable annual returns, which accentuated the process of transforming resources through capital and labor. Moreover, Kates et al. [11] expanded the concept from several facets, indicating sustainability was an open, dynamic and evolving idea that required participation of diverse perspectives, such as nature, human, economy and society, and reconciliation of different and sometimes opposite goals. Based on relevant studies, Kuhlman and Farrington [16] pointed out that the traditional three dimensions of sustainability, namely economy, society and 
environment, should combine with human well-being to embody the interrelationships of factors from different dimensions. However, Imran et al. [17] believed sustainability not only emphasized human well-being, but also became eco-centered to achieve the well-being of all creatures. Besides, Manderson [18] stated sustainability was the interactions among multi systems, which had different contents under diverse background, covering resource, economy, society, industry, city, etc. Ostrom [19] further considered the sustainability of social-eco system according to the interactions of many subsystems such as resource, user and supervision.

To sum up, the concept of sustainability is expanded from two-dimensions to three-dimensions, i.e., economy, environment and society, and considers several other dimensions and subsystems to search for the coordination and long-term development of factors, where capital is an essential facet.

\subsubsection{Sustainability and PPP Projects}

Sustainability should be applied throughout the life-cycle of PPP projects. Villalba-Romero et al. [20] analyzed the sustainability of PPP projects from the traditional aspects (economy, society and environment), considering finance, construction, operation and other phrases of PPP projects. Combining the characteristics of PPP projects with sustainability. Xiong and Chu [21] proposed an original PPP 3.0 strategy to strengthen financial function, improve construction efficiency and protect sustainable developments of the society, economy and environment. Moreover, Zhang et al. [22] divided the sustainability of PPP projects into five facets: construction, economy, society, environment and management. Economic sustainability has close relationship with the Value for Money framework, while the environmental sustainability influences the financial ability of PPP projects [23]. Besides, operational sustainability, political sustainability and technological sustainability are necessary parts of sustainable development in PPP projects [24]. Furthermore, partnership is an important point of sustainability in PPP projects. Building sustainable contractual relationship is benefit to the achievement of social benefits and the improvement of future social values of PPP projects [25]. In addition, objective consistency, long-term cooperation, equal coordination and benefit-risk sharing relationship among government, private company and public should be considered to maintain sustainable partnerships in PPP projects [26].

In light of the above, the introduction of sustainability provides new ideas of PPP projects in several facets, where financial aspect is the core one. Therefore, sustainability has close relationship with the capital structure of PPP projects. Nevertheless, current studies initially focus on the theory level rather than applying sustainability to the specific phrase of PPP projects, which should be improved in the future.

\subsection{Capital Structure and Its Application in PPP Projects}

\subsubsection{General Concept of Capital Structure}

Capital structure is the structure of debt and equity funds in the corporate finance, which is a dynamic and complex process that represents the investment behavior of investors and the corporation value [27]. The theories of capital structure developed through several stages, including traditional capital structure theory [28], MM theory [29] and its revision [30,31], trade-off theory [32,33], agency cost theory [34], signaling theory [35], corporate control theory [36-38] and industry organization model [39]. To sum up, capital structure theories explain the relationship between the capital structure and corporation value and analyze the rational management and maximum benefits, which can also be applied to PPP projects.

Moreover, there are many studies about the capital structure. Onaolapo et al. [40] indicated the leverage ratio had negative impact on the profitability, while the firm size and asset tangibility had positive influence on the leverage proxies. Meanwhile, Feld et al. [41] investigated that taxation had positive impact on the equity-debt ratio. Besides, many new firms rely on debt funds [42], while family firms prefer equity capital rather than debt funds [43]. As for the costs of debt and equity, weighted 
average cost of capital (WACC) is a commonly used indicator, which considers the costs of different sources and their proportion [44]. Additionally, the project-specific WACC can be applied to reflect the character of the individual PPP projects [45]. In the formula of WACC, $\mathrm{K}_{\mathrm{e}}$ and $\mathrm{K}_{\mathrm{d}}$ are two important indicators. $\mathrm{K}_{\mathrm{e}}$ is the cost of equity, that is, the expected return of equity provider, which is often calculated by the Capital Asset Pricing Model (CAPM) [46], while $K_{d}$ means the cost of debt that covers the loans, bonds and other resources [47]. These indicators are all important in the analysis of capital structure.

\subsubsection{Capital Structure of PPP Projects}

Many researchers analyzed the capital structure of PPP projects from different aspects such as benefit, financial cost, risk, etc.

First, from the perspective of benefit, Sharma et al. [48] indicated the best equity-investment ratio should maximize the benefits of private funds when the public interests can be guaranteed. Moreover, Sheng et al. [49] used the maximization of private sector's benefits as the goal to determine the equity structure and combined the project cash flow forecast with benefit functions of stakeholders to get reasonable capital structure. Toms et al. [50] also pointed out that the investments of partners should be equal to the benefits they can obtain to achieve the stability of cooperation in PPP projects.

Second, financial cost also attracts many researchers' concerns. It plays an integral part of life-cycle costs in PPP projects and has deep relationship with risk sharing and transitional costs of bank [51]. Tao and Ji [52] believed financing cost rate was related to the return rate of investment and financing efficiency which were the basis of government's investment decision. Furthermore, Demirag et al. [53] indicated the increase of financing costs, the shortage of equity funds and short-term debt preference led to the difficulties of risk avoidance in England PPP projects. Thus, government should consider the characteristics and preferences of equity and debt investment of private sector in PPP projects.

Third, risk is a necessary part in the analysis of capital structure. Zhang [4] analyzed the capital structure of PPP projects considering construction risk, financial bankruptcy risk and other economic risks from different stakeholders. Moreover, Yun et al. [54] used Monte-Carlo simulation to analyze the risks of lenders and operators and optimized the capital structure through multi-objective genetic algorithm. Then, Demirag et al. [55] indicated different investors cared about different risks: an equity investor focuses on the equal distribution of risks, while a debt investor prefers low-risk projects. However, the indicators of investment decision-making are alike, including economic indicators, internal rate of return, investment return period, etc., and non-economic indicators, reputation, familiarity, experience, etc. Internal rate of return is the most popular indicators while there are many unreasonable points [56]. Average internal rate of return is a better indicator [57].

Besides, government support is a key point. Transportation Infrastructure Finance and Innovative Act is a project supporting important transportation PPP projects, which accounts for $7 \%$ of the total funds of PPP projects in America [58]. Shuai and Hubo [59] indicated government stimulation was deeply related with investment of private sector. The income guarantee, extended period of concession and one-time or unit subsidy all promote the increase of equity-investment from private sector.

Considering above, researchers analyzed the capital structure from many aspects. However, recent studies care more about the quantitative model rather than the systematic analysis of critical factors. Moreover, these studies rely on economic indicators ignoring the impacts on long-term healthy operation of PPP projects. Therefore, this study analyzed the critical factors influencing capital structure of PPP projects from the sustainability perspective to provide references for selection of the capital structure in practice. 


\section{Methodology}

\subsection{Literature Analysis}

Literature analysis identified critical factors through the systematic analysis and organization of relevant literature [60]. It was chosen in this study due to its clear and reliable process that achieves the objective and comprehensive identification of critical factors, while other methods, such as questionnaire and case study, are more suitable for the subsequent analysis of critical factors instead of the primary identification [61-63]. This study used a four-step process to identify critical factors on capital structure of PPP projects as Figure 1.

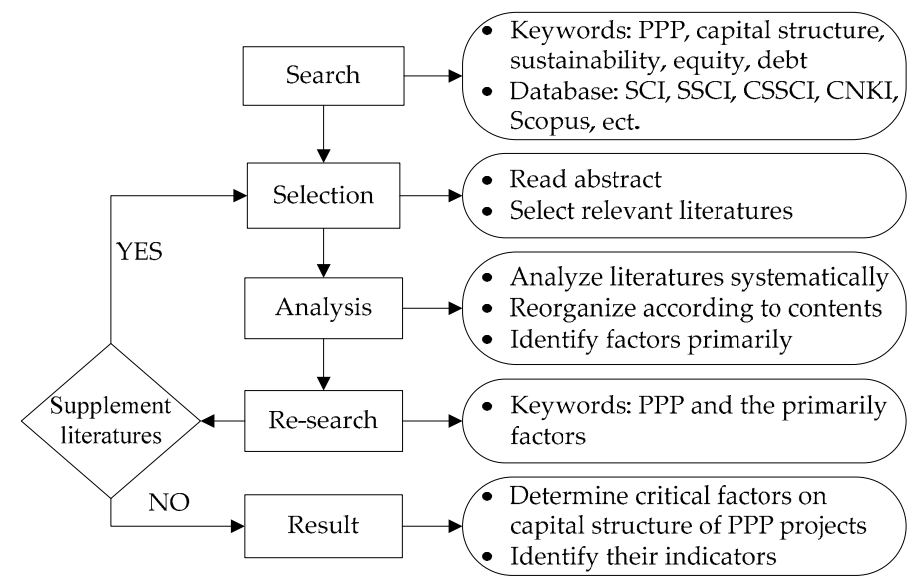

Figure 1. Identification process of critical factors on capital structure of PPP projects.

First, this study used PPP, capital structure, sustainability, equity and debt as key words to search for literature in the Scopus. More than 500 studies were searched covering many databases, such as Science Citation Index, Social Science Citation Index, China National Knowledge Infrastructure, etc. Second, after skimming the abstracts and learning about the core contents, more than 100 studies closely related to the research topic were selected. Then, through full-text reading and analysis, seven influencing factors were identified primarily. Based on these factors, the studies were culled again to get 58 core studies and then they were reclassified. After that, it is necessary to research supplementary literature using PPP and each factor as key word, respectively. When no supplement literature in direct relationship with this topic was missing, the seven critical factors and their indicators were determined with references to 65 studies. These factors are benefit, risk, ability, cost, project condition, government support and external situation.

\subsection{Qualitative Comparative Analysis (QCA)}

Qualitative Comparative Analysis (QCA) is a method using quantitative analysis of data from several cases to make up the insufficiency of qualitative analysis and interpreting the quantitative results by qualitative analysis $[64,65]$. It is suitable for small samples, medium-scale samples and large-scale samples [66,67], while small and medium samples are more common $[64,68]$. It has been applied to investigate the relationships between the critical factors and outcomes $[65,68,69]$. As popular methods of analyzing critical factors, questionnaire survey requires a large amount of data and detailed analysis by other techniques [61,62], while single-case study cannot get a general finding due to its limitation of one case [70]. Therefore, QCA is a suitable method that can achieve a comprehensive result based on the data of real cases [65,71]. Additionally, the configuration analysis, as the core of QCA, realizes the analysis of multiple concurrent causality [72]. The causal relationship depends on the situation and configuration. This is in accordance with the complexity of relationships between the capital structure and its critical factors. The mainstream statistical methods should be applied under 
strict constraints and hypotheses that are not suitable for the capital structure of PPP projects [66]. Besides, the replicability and transparency of process can strengthen the reliability of results [66]. QCA has been widely used in studies of a similar nature (e.g., [70,71,73-75]).

Therefore, QCA was applied in this study based on 15 PPP projects to investigate the relationship between the critical factors and capital structure of PPP projects.

Due to the complexity of capital structure, it cannot be represented by a single indicator [27]. Therefore, this study chose equity-debt ratio and equity-investment ratio of private sector as the dependent variables. The equity-debt ratio is the most important indicator of the capital structure that obtains many researchers' attentions and can be quantified clearly [39,41-43]. Meanwhile, the equity-investment ratio of private sector is also very essential and determines the equity structure because the private sector is the major equity provider in PPP projects. Therefore, the two dependent variables can represent the results of capital structure in PPP projects.

Moreover, seven critical factors were independent variables. In PPP projects, the content of each variable can be shown clearly by the binary threshold (" 1 " indicating full membership in the set and " 0 " indicating non-membership [66]). Thus, crisp set QCA (csQCA), where each variable is a dichotomous variable and assigned one of two possible membership scores by binary threshold [66], was selected to investigate the relationships between factors and the capital structure of PPP projects. The process is shown in Figure 2.

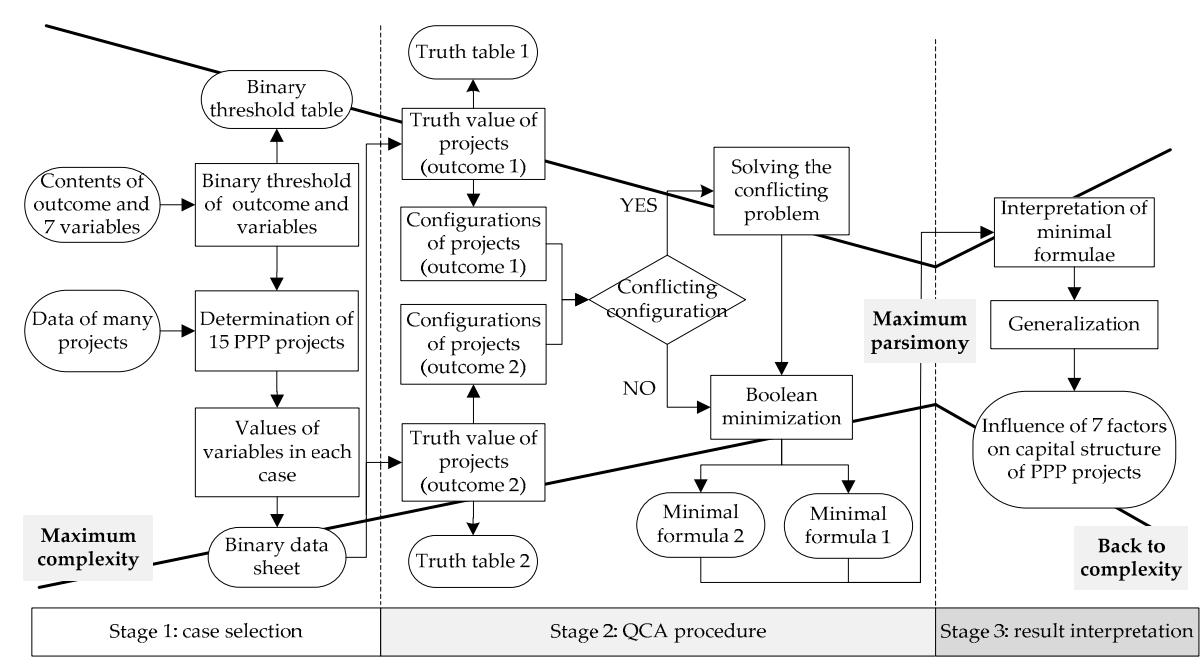

Figure 2. Case-based QCA procedure.

\subsubsection{Case Selection}

Data of cases are the basis of QCA, which means the reasonability of case selection can directly impact the reliability of the results. Therefore, case selection follows the scientific procedure shown in Figure 2. This study used successful PPP projects as cases to investigate the factors influencing capital structure. First, many PPP projects with ample data were collected covering different countries and types to represent the maximum complexity of reality. Next, according to the contents of seven factors, this study determined the binary threshold of each factor as the rule of assignment of every case. Then, based on the information of 15 PPP projects, each variable was assigned " 0 " or " 1 ", obtaining the binary data sheet as the basic data of QCA.

\subsubsection{Qualitative Comparative Analysis}

After the selection of 15 successful PPP projects, this study applied TOSMANA software to analyze the configurations using csQCA method [66]. There are two dependent variables in this study, thus two analyses were conducted. First, this study integrated the configurations of 15 cases to get the 
truth table and configurations of each outcome. The cases that have the same value of each variable show the same configuration and should be conflated. Moreover, the truth table shows the binary data of all different configurations, when one configuration has one or more corresponding cases [67]. Then, if there is conflicting configuration, adjusting variables and changing cases are useful methods to solve the conflicting problem. When there was no conflicting configuration, Boolean minimization was conducted to minimize these formulae of configurations under each outcome and get the final minimal formulae. This process narrows the maximum complexity of reality to maximum parsimony of formulae [67].

\subsubsection{Result Analysis}

Comparing and analyzing the results of two QCA processes, it is necessary to illustrate each formula that represents the relationships between factors and outcomes. Thus, the changes of equity-debt ratio and equity-investment ratio of private sector under the variations of critical factors can be explicated to achieve the scientific analysis of critical factors influencing capital structure of PPP projects from a sustainability perspective. Though this step, the maximum parsimony can be back to complexity linking with practice [67].

\section{Identification and Analysis of Critical Factors on Capital Structure of PPP Projects}

\subsection{Identification of Critical Factors Based on the Literature}

The frequencies of seven factors appearing in the 65 studies are shown in Figure 3.

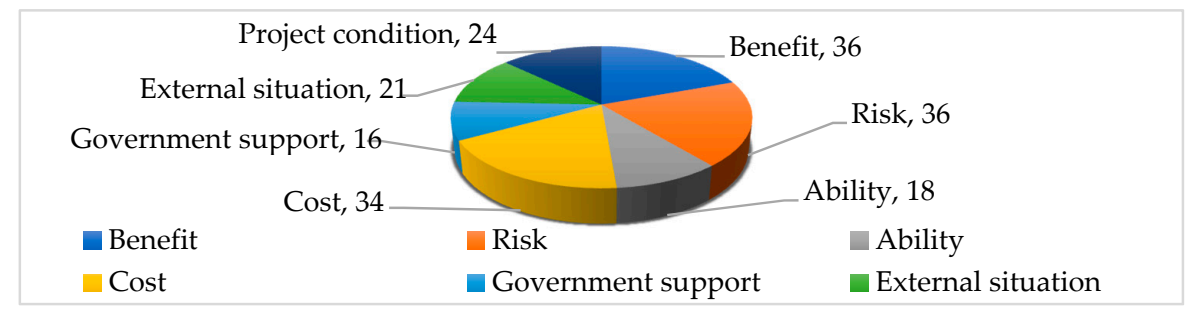

Figure 3. Frequencies of factors in 65 studies.

Risk and benefit are the most frequently mentioned factors, for more than 36 times, covering $56 \%$ each. Then, cost is also very important and accounts for $53 \%$. Besides, project condition and external situation draw many researchers' attention. More than 20 studies referred to each factor. Finally, ability and government support are indicators that cannot be ignored. More than 15 studies illustrated at least one of the two factors. In light of the above, all seven factors are important for the capital structure in PPP projects. The studies and their relationships with critical factors are shown in Table 1.

Table 1. Results of literature analysis.

\begin{tabular}{cccccccc}
\hline \multirow{2}{*}{ NO. } & References & \multicolumn{6}{c}{ Critical Factors } \\
\cline { 3 - 7 } & & Benefit & Risk & Ability & Cost & $\begin{array}{c}\text { Government External } \\
\text { Support }\end{array}$ & $\begin{array}{c}\text { Project } \\
\text { Situation Condition }\end{array}$ \\
\hline 1 & Jr. and Ioannou [76] & $\sqrt{ }$ & & $\sqrt{ }$ & $\sqrt{ }$ & & \\
2 & Pantelias and Zhang [77] & $\sqrt{ }$ & $\sqrt{ }$ & & $\sqrt{ }$ & & $\sqrt{ }$ \\
3 & Chen et al. [78] & $\sqrt{ }$ & $\sqrt{ }$ & & $\sqrt{ }$ & $\sqrt{ }$ & $\sqrt{ }$ \\
4 & Chen et al. [79] & $\sqrt{ }$ & & & $\sqrt{ }$ & $\sqrt{ }$ & $\sqrt{ }$ \\
5 & Thompson and McKee [80] & & & $\sqrt{ }$ & & $\sqrt{ }$ & \\
6 & Daube et al. [51] & & $\sqrt{ }$ & & $\sqrt{ }$ & & \\
7 & Ramsey and Asmar [58] & & & & & & \\
8 & Demirag et al. [55] & $\sqrt{ }$ & $\sqrt{ }$ & $\sqrt{ }$ & & & \\
9 & Demirag et al. [53] & & & $\sqrt{ }$ & $\sqrt{ }$ & & \\
\hline
\end{tabular}


Table 1. Cont.

\begin{tabular}{|c|c|c|c|c|c|c|c|c|}
\hline \multirow{2}{*}{ NO. } & \multirow{2}{*}{ References } & \multicolumn{7}{|c|}{ Critical Factors } \\
\hline & & Benefit & Risk & Ability & Cost & $\begin{array}{l}\text { Government } \\
\text { Support }\end{array}$ & $\begin{array}{l}\text { External } \\
\text { Situation }\end{array}$ & $\begin{array}{l}\text { Project } \\
\text { Condition }\end{array}$ \\
\hline 10 & Devapriya [81] & & & $\sqrt{ }$ & & & $\sqrt{ }$ & \\
\hline 11 & Feng et al. [82] & $\sqrt{ }$ & $\sqrt{ }$ & & $\sqrt{ }$ & & & \\
\hline 12 & Sheng et al. [49] & & & $\sqrt{ }$ & $\sqrt{ }$ & & $\sqrt{ }$ & $\sqrt{ }$ \\
\hline 13 & DU et al. [83] & $\sqrt{ }$ & $\sqrt{ }$ & & $\sqrt{ }$ & & & \\
\hline 14 & Iyer and Sagheer [84] & $\sqrt{ }$ & & & $\sqrt{ }$ & $\sqrt{ }$ & & \\
\hline 15 & Singh and Kalidindi [85] & & $\sqrt{ }$ & $\sqrt{ }$ & & & $\sqrt{ }$ & $\sqrt{ }$ \\
\hline 16 & Li et al. [86] & & & & & $\sqrt{ }$ & & \\
\hline 17 & Moszoro [87] & & & $\sqrt{ }$ & $\sqrt{ }$ & $\sqrt{ }$ & $\sqrt{ }$ & \\
\hline 18 & Haran et al. [88] & & & $\sqrt{ }$ & & $\sqrt{ }$ & $\sqrt{ }$ & \\
\hline 19 & Regan et al. [89] & & $\sqrt{ }$ & & $\sqrt{ }$ & $\sqrt{ }$ & $\sqrt{ }$ & \\
\hline 20 & Zhu and Wang [90] & $\sqrt{ }$ & & & & $\sqrt{ }$ & & \\
\hline 21 & Regan et al. [91] & & $\sqrt{ }$ & & & & $\sqrt{ }$ & $\sqrt{ }$ \\
\hline 22 & Bakatjan et al. [92] & $\sqrt{ }$ & & & $\sqrt{ }$ & & & \\
\hline 23 & Sundararajan and Tseng [93] & $\sqrt{ }$ & $\sqrt{ }$ & & $\sqrt{ }$ & & & \\
\hline 24 & Sharma et al. [48] & $\sqrt{ }$ & $\sqrt{ }$ & & $\sqrt{ }$ & & & $\sqrt{ }$ \\
\hline 25 & Shuai and Hubo [59] & $\sqrt{ }$ & $\sqrt{ }$ & $\sqrt{ }$ & $\sqrt{ }$ & & & $\sqrt{ }$ \\
\hline 26 & Toms et al. [50] & $\sqrt{ }$ & & $\sqrt{ }$ & & $\sqrt{ }$ & $\sqrt{ }$ & \\
\hline 27 & Tao and Ji [52] & $\sqrt{ }$ & $\sqrt{ }$ & $\sqrt{ }$ & $\sqrt{ }$ & & & \\
\hline 28 & Yun et al. [54] & & $\sqrt{ }$ & & $\sqrt{ }$ & & & $\sqrt{ }$ \\
\hline 29 & Zhang [4] & & $\sqrt{ }$ & & & $\sqrt{ }$ & & \\
\hline 30 & Atmo et al. [23] & & & & & & $\sqrt{ }$ & $\sqrt{ }$ \\
\hline 31 & Bian [94] & $\sqrt{ }$ & $\sqrt{ }$ & & $\sqrt{ }$ & & $\sqrt{ }$ & $\sqrt{ }$ \\
\hline 32 & Chen [95] & $\sqrt{ }$ & $\sqrt{ }$ & $\sqrt{ }$ & & & & \\
\hline 33 & Deng [96] & $\sqrt{ }$ & $\sqrt{ }$ & & & & & \\
\hline 34 & Dong [97] & $\sqrt{ }$ & $\sqrt{ }$ & & & & $\sqrt{ }$ & \\
\hline 35 & $\mathrm{Du}[98]$ & $\sqrt{ }$ & $\sqrt{ }$ & & & & & \\
\hline 36 & Grimsey and Lewis [99] & & $\sqrt{ }$ & & $\sqrt{ }$ & & & \\
\hline 37 & Feng et al. [100] & $\sqrt{ }$ & & & & & & \\
\hline 38 & Guan [101] & & & & & & $\sqrt{ }$ & \\
\hline 39 & Hu et al. [102] & $\sqrt{ }$ & $\sqrt{ }$ & & $\sqrt{ }$ & & $\sqrt{ }$ & $\sqrt{ }$ \\
\hline 40 & Jiang and Zhou [103] & & & & $\sqrt{ }$ & & $\sqrt{ }$ & \\
\hline 41 & Jiang and Tang [104] & $\sqrt{ }$ & $\sqrt{ }$ & & & & & $\sqrt{ }$ \\
\hline 42 & Li [105] & $\sqrt{ }$ & $\sqrt{ }$ & & & & $\sqrt{ }$ & $\sqrt{ }$ \\
\hline 43 & Li and Zhang [106] & & & & & $\sqrt{ }$ & $\sqrt{ }$ & $\sqrt{ }$ \\
\hline 44 & Li [107] & & $\sqrt{ }$ & & $\sqrt{ }$ & $\sqrt{ }$ & $\sqrt{ }$ & $\sqrt{ }$ \\
\hline 45 & Li [108] & $\sqrt{ }$ & & $\sqrt{ }$ & & & & \\
\hline 46 & Liu et al. [109] & & & & & & & $\sqrt{ }$ \\
\hline 47 & Liu [110] & $\sqrt{ }$ & $\sqrt{ }$ & & & & & \\
\hline 48 & Zhao et al. [111] & $\sqrt{ }$ & $\sqrt{ }$ & & & & & \\
\hline 49 & Na et al. [112] & & $\sqrt{ }$ & $\sqrt{ }$ & $\sqrt{ }$ & & & \\
\hline 50 & Ye et al. [113] & $\sqrt{ }$ & & & $\sqrt{ }$ & & & \\
\hline 51 & Shen and Nan [114] & & $\sqrt{ }$ & & & & & $\sqrt{ }$ \\
\hline 52 & Shen [115] & & $\sqrt{ }$ & & $\sqrt{ }$ & & & $\sqrt{ }$ \\
\hline 53 & Sheng [116] & $\sqrt{ }$ & $\sqrt{ }$ & & $\sqrt{ }$ & & $\sqrt{ }$ & $\sqrt{ }$ \\
\hline 54 & Sheng et al. [117] & $\sqrt{ }$ & & $\sqrt{ }$ & & & & \\
\hline 55 & Tang [118] & $\sqrt{ }$ & & & $\sqrt{ }$ & & & $\sqrt{ }$ \\
\hline 56 & Shi [119] & $\sqrt{ }$ & $\sqrt{ }$ & & $\sqrt{ }$ & $\sqrt{ }$ & & \\
\hline 57 & Yang [120] & & & & $\sqrt{ }$ & $\sqrt{ }$ & $\sqrt{ }$ & \\
\hline 58 & Du and $X_{v}[121]$ & $\sqrt{ }$ & $\sqrt{ }$ & & & & $\sqrt{ }$ & $\sqrt{ }$ \\
\hline 59 & Ye and Zhang [122] & & $\sqrt{ }$ & & & & & \\
\hline 60 & Yue and Huang [123] & $\sqrt{ }$ & $\sqrt{ }$ & & $\sqrt{ }$ & & & \\
\hline 61 & Zhang [124] & $\sqrt{ }$ & & & $\sqrt{ }$ & & & \\
\hline 62 & Zhang [125] & & & $\sqrt{ }$ & & & & $\sqrt{ }$ \\
\hline 63 & Zhang and $X_{V}[126]$ & & $\sqrt{ }$ & $\sqrt{ }$ & & $\sqrt{ }$ & & $\sqrt{ }$ \\
\hline 64 & Sun et al. [127] & $\sqrt{ }$ & & & $\sqrt{ }$ & & & \\
\hline 65 & Shen and Nan [128] & & & & $\sqrt{ }$ & $\sqrt{ }$ & & \\
\hline & Total & 36 & 36 & 18 & 34 & 16 & 21 & 24 \\
\hline & lotal & $56 \%$ & $56 \%$ & $28 \%$ & $53 \%$ & $25 \%$ & $33 \%$ & $38 \%$ \\
\hline
\end{tabular}




\subsection{Analysis of Factors}

Contents and indicators of the seven critical factors are shown in Table 2. The benefit, risk, cost, ability and project condition are internal factors that represent the situation of project itself or the private sector, while the government support and external situation are external factors that care about the outside condition's impact on the capital structure of PPP projects. Besides, each factor has several indicators from both project level and social level that illustrate the contents of factors clearly and help to determine the binary data of cases.

Table 2. Contents and indicators of critical factors.

\begin{tabular}{|c|c|c|c|c|}
\hline \multirow{2}{*}{ Category } & \multirow{2}{*}{ Factor } & \multirow{2}{*}{ Content } & \multicolumn{2}{|c|}{ Indicator } \\
\hline & & & Project Level & Social Level \\
\hline \multirow{5}{*}{ Internal } & Benefit & $\begin{array}{l}\text { Benefits for participants in } \\
\text { PPP projects from economic } \\
\text { and non-economic perspective }\end{array}$ & $\begin{array}{l}\text { Benefits for investor; } \\
\text { Benefits for creditor; }\end{array}$ & Public interest \\
\hline & Risk & $\begin{array}{l}\text { Different kinds of risks during } \\
\text { the life-cycle of PPP projects }\end{array}$ & $\begin{array}{l}\text { Financial risk; Construction } \\
\text { risk; Operation risk; }\end{array}$ & $\begin{array}{c}\text { Social risk; } \\
\text { Environmental risk }\end{array}$ \\
\hline & Ability & $\begin{array}{l}\text { Abilities of private sector } \\
\text { during the implementation of } \\
\text { PPP projects }\end{array}$ & $\begin{array}{l}\text { Investment ability; } \\
\text { construction ability; } \\
\text { Operation ability; Life-cycle } \\
\text { management ability }\end{array}$ & \\
\hline & Cost & $\begin{array}{l}\text { The resources for PPP projects } \\
\text { including money and other } \\
\text { intangible costs }\end{array}$ & $\begin{array}{c}\text { Financial cost; Construction } \\
\text { cost; Operation and } \\
\text { maintenance cost }\end{array}$ & $\begin{array}{c}\text { Social cost; } \\
\text { Environment cost }\end{array}$ \\
\hline & $\begin{array}{l}\text { Project } \\
\text { condition }\end{array}$ & $\begin{array}{l}\text { The conditions and characters } \\
\text { of PPP projects }\end{array}$ & $\begin{array}{l}\text { Investment size; Project type; } \\
\text { Profitability; Credit rating }\end{array}$ & \\
\hline \multirow{2}{*}{ External } & $\begin{array}{l}\text { Government } \\
\text { support }\end{array}$ & $\begin{array}{l}\text { Support and supervision } \\
\text { measures from government in } \\
\text { PPP projects }\end{array}$ & $\begin{array}{l}\text { Equity incentive; } \\
\text { Financial support }\end{array}$ & $\begin{array}{l}\text { Standard operation; } \\
\text { Preferential policy }\end{array}$ \\
\hline & $\begin{array}{l}\text { External } \\
\text { situation }\end{array}$ & $\begin{array}{l}\text { The external situation } \\
\text { influencing PPP projects }\end{array}$ & & $\begin{array}{l}\text { Capital market; Laws } \\
\text { and regulations; } \\
\text { Industry situation }\end{array}$ \\
\hline
\end{tabular}

1) Benefit

Benefit is the core issue that all participants of PPP projects care about [129]. In many models of the capital structure in PPP projects, it is the most important indicator [48]. As the investor of PPP projects, the private sector is concerned with return of investment [92], while the public sector cares more about the public interests, such as social and environment benefits rather than economic benefits [48]. Besides, the financing institution focuses on the stability of repayment of debt funds and the benefits of creditors [79].

2) Risk

Risk appears throughout the life-cycle of PPP projects [3] and has close relation with the capital structure [55]. First, the capital structure is an integral part of the financial phrase in PPP projects, thus financial risk is an important indicator [77]. Second, construction impacts the quality and operation of projects, which means construction risk cannot be ignored [83]. Moreover, operational stage covers most of the contract period, thus its result directly influences the achievement of targets in PPP projects. Therefore, operation risk should be paid enough attention by stakeholders [4]. Besides, general public is the end-user and actual provider of governmental funds [130]. The social risk and environment risk that correlate with public are essential. 
3) Ability

As the implementor of PPP projects that undertakes the major financing work, the ability of private sector is very important [131]. Investment ability is not only an important indicator when the public sector selects proper partner [132], but also the critical aspect that financial institutions care when they provide debt funds [55]. Moreover, construction ability, operation ability and life-cycle management ability all impact the success of PPP projects. Therefore, the public sector and financial institution both take these into account to analyze the future cash flow of projects to select proper capital structure [79].

4) Cost

Similar to benefit, cost has been widely applied and analyzed in many models and formulae of the capital structure in PPP projects [49]. The minimization of financing cost is the core objective of capital structure [54]. Moreover, operation and maintenance last for a long period in PPP projects, thus costs of operation and maintenance play an important role in the cash flow of PPP projects that relates closely with selection of the capital structure [84]. Besides, intangible costs of PPP projects such as social costs and environmental costs also should be concerned in the capital structure to guarantee the success of PPP projects [87].

\section{5) Project condition}

Profitability is a key indicator that financial institution considers when providing funds. As for non-profit PPP projects, such as public medical institution, it would be harder to finance enough funds without assistant measures comparing with projects that have strong profitability [80]. Furthermore, considering the characters of different industries, the equity-debt ratio and resources of funds would be diverse due to its project type [85]. Additionally, investment scale determines the total amount of funds of projects, which suits for different equity-debt ratio [90]. Besides, credit rating is a necessary supporting indicator for financial institution [55].

\section{6) Government support}

As initiator and supervisor of PPP projects, government supports from several facets have essential impact on the capital structure. Financial support is the major aid from government to strengthen cash flow of PPP projects through minimum rate of return guarantees, subsidizes, etc. [78]. Thus, PPP projects can obtain sufficient funds with lower financial costs [82]. Moreover, equity incentive is also an important measure adopted by government. Injecting of public funds not only stimulates the investment of private sector, but also improves the financial institutions' confidence in PPP projects [59]. Besides, the preferential policies of relevant industries and regions and the government's supervision of standard operation can help projects to get ample funds to promote the healthy operation of PPP projects [52].

7) External situation

Capital market indicates the whole situation of capital operation. The development trend and condition of capital market have indispensable impact on the finance of different kinds of projects including PPP projects [53]. When determining the capital structure, every participant should consider conditions of capital market to make decisions that are suitable for current situation [91]. Moreover, industry condition shows the current status and trend of different sectors especially in the location of PPP projects, which would influence the confidence and investment behavior of investor and creditor [23]. Besides, laws and regulations are important for the capital structure through influencing the implementation and cash flow of PPP projects [81]. 


\section{Impact of Sustainability on Capital Structure of PPP Projects}

Sustainability is an important and international trend, which should be concerned in PPP projects. The core concept of sustainability is that current behavior should not impact future development from three aspects: economy, society and environment $[10,16]$. Capital structure of PPP projects from a sustainability perspective means current capital structure should neither influence the future development of PPP projects nor bring about any bad impacts on the environment and public of the industry, region and even the whole society. That is, PPP projects can achieve life-cycle healthy operation to guarantee the economic, social and environmental benefits rather than just satisfying current funds demand.

However, previous studies of the capital structure in PPP projects mostly relied on economic indicators while ignoring the sustainability $[79,92]$. In practice, sustainability has not been embodied in PPP projects, which means participants cares more about the short-term demand of funds rather than long-term development of projects when deciding the capital structure. Therefore, this study introduced sustainability into the analysis of capital structure in PPP projects to promote long-term healthy operation and development of PPP projects.

The framework of critical factors influencing capital structure of PPP projects under the sustainability is shown in Figure 4. The shaded areas show the indicators that closely relate to sustainability. All seven factors have deep relationship with sustainability.

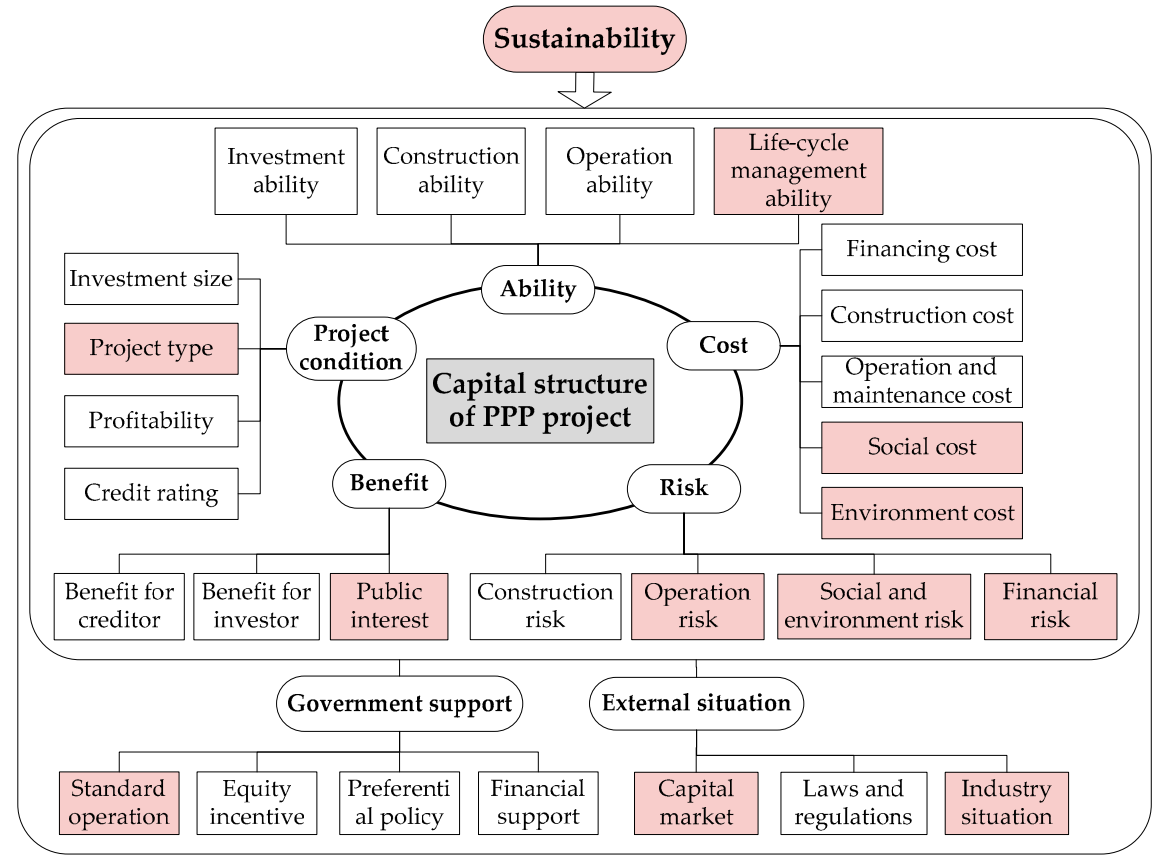

Figure 4. Critical factors influencing capital structure of PPP projects from a sustainability perspective.

\section{1) Public interest}

Traditional capital structure often cares about benefits of investors and creditors [48]. From a sustainability perspective, public interest should be concerned in the capital structure of PPP projects. Many problems that will harm public interests, such as too high rate of return of the private sector, should be avoided to assure the social and environmental benefits of PPP projects and improve the healthy impact on the sustainable development of industry, region and society.

2) Risks 
Analyzing risks under the context of sustainability is more comprehensive. Combining the life-cycle cash flow prediction and analysis with the future development and long-term effects of PPP projects, the financial risks can be analyzed reasonably. Moreover, operation stage covers a long period of PPP projects, which directly impact the healthy operation result. Thus, operation risks should be evaluated considering sustainability to maintain the successful operation of PPP projects. Besides, social risk and environmental risk that link with long-term effects are important indicators from a sustainability perspective.

\section{3) Social and environment costs}

From a sustainability perspective, social and environmental costs caused by different capital structure are essential indicators. It is inconsistent with sustainability to make irretrievable damage to public lives, natural environment or the region to achieve the economic targets of investors. Too high social and environmental costs of PPP projects should be avoided in the capital structure. Thus, the intangible costs should be reasonably evaluated to realize the healthy and sustainable operation of PPP projects and do not influence the future development of the region and whole society.

4) Life-cycle management ability

Considering the abilities of private sector, life cycle management ability of the private sector should be concerned from a sustainability perspective, because it impacts the efficiency, relationship, profitability and future development of PPP projects [132]. Fully considering the life-cycle management condition helps the participants to build reasonable capital structure to achieve the targets of projects and promote the development of industry, region and society.

5) Standard operation

In terms of government support, standard operation has the closest correlation with sustainability. Supervising the behaviors of each participant and assuring the standard operation are key tasks of government [130]. Standard operation not only guarantees the efficient and healthy operation of PPP projects, but also strengthens the confidences of financiers and investors to incentivize investment behaviors and change the capital structure.

\section{6) Project type}

Different types of projects have different financial abilities and social and environmental effects. Participants should consider the character and trend of industry to design the capital structure that is suitable for the project type to protect the stability of funds during the life-cycle of PPP projects. In this way, the economic, social and environmental objectives can be realized to promote the development of projects, industry and regional economy.

7) Capital market and industry situation

As for external situation, participants should care about the characters of the capital market and industry of project. Capital structure that suits the preference of the capital market and follows the trend of industry can provide ample funds for the construction and operation to assure the long-term successful operation of PPP projects. Meanwhile, successful PPP projects can support the complete of capital market and development of industry.

In other words, analyzing the capital structure of PPP projects from a sustainability perspective emphasizes the non-economic indicators as well as the traditional economic indicators. Combined with these factors, the capital structure can become more scientific to guarantee the success of PPP projects and lead to good effect on the industry, region and society. 


\section{Case-Based Qualitative Comparative Analysis}

\subsection{Case Selection and Data}

The 15 successful PPP projects are either from Chinese national demonstrative project database or were widely recognized by researchers and practitioners [9,133-136], covering several sectors, such as transportation, hospital, waste, etc., and different countries such as China, Germany, Canada, etc. With the application of many modes including build-operate-transfer (BOT), design-build-finance-operate-maintain (DBFOM), transfer-operate-transfer (TOT) and rebuild-operate-transfer (ROT), the 15 PPP projects can represent the complexity of reality. The basic information is shown in Table 3.

Table 3. Basic information of 15 PPP projects.

\begin{tabular}{|c|c|c|c|c|c|c|}
\hline Case ID & Title & Country & $\begin{array}{c}\text { Investment } \\
\text { (Billion Dollars) }\end{array}$ & Mode & $\begin{array}{l}\text { Equity-Debt } \\
\text { Ratio }\end{array}$ & $\begin{array}{c}\text { Equity-Investment } \\
\text { Ratio of Private Sector }\end{array}$ \\
\hline 1 & Beijing Metro Line 4 & China & 2.42 & BOT & $1 / 2$ & $98 \%$ \\
\hline 2 & $\begin{array}{l}\text { Guangdong Shajiao B } \\
\text { power plant }\end{array}$ & China & 0.54 & BOT & $1 / 3$ & $50 \%$ \\
\hline 3 & Shuohuang Railway & China & 2.78 & BOT & $3 / 7$ & $52.70 \%$ \\
\hline 4 & $\begin{array}{c}\text { Malaysia's North-South } \\
\text { highway }\end{array}$ & Malaysia & 1.28 & BOT & $1 / 9$ & $100 \%$ \\
\hline 5 & $\begin{array}{c}\text { Chengdu No. } 6 \text { Water } \\
\text { Plant B Part }\end{array}$ & China & 0.11 & BOT & $3 / 7$ & $100 \%$ \\
\hline 6 & $\begin{array}{c}\text { Wasser Water Project in } \\
\text { Berlin }\end{array}$ & Germany & 0.83 & BOT & $3 / 5$ & $50 \%$ \\
\hline 7 & The Second Severn Bridge & Britain & 1.08 & DBFOM & $1 / 9$ & $100 \%$ \\
\hline 8 & $\begin{array}{l}\text { Sludge Treatment Project } \\
\text { in Sudbury }\end{array}$ & Canada & 0.06 & DBFOM & $1 / 9$ & $100 \%$ \\
\hline 9 & M5 Toll Road in Hungary & Hungary & 0.46 & BOT & $2 / 9$ & $80 \%$ \\
\hline 10 & $\begin{array}{l}\text { Beiras Litoral and Alta } \\
\text { Shadow Toll Road }\end{array}$ & Portugal & 1.42 & BOT & $4 / 41$ & $100 \%$ \\
\hline 11 & $\begin{array}{c}\text { International Airport } \\
\text { Hamburg AG }\end{array}$ & Germany & 0.43 & BOT & $3 / 5$ & $40 \%$ \\
\hline 12 & $\begin{array}{l}\text { Zhongdu Medical and } \\
\text { Nursing Combined } \\
\text { Project in Shandong }\end{array}$ & China & 0.13 & $\mathrm{BOO}$ & $1 / 4$ & $95 \%$ \\
\hline 13 & $\begin{array}{c}\text { Sewage Treatment Plant } \\
\text { and Pipe Network Project } \\
\text { in Langxi }\end{array}$ & China & 0.06 & $\mathrm{TOT}+\mathrm{BOT}$ & $1 / 6$ & $100 \%$ \\
\hline 14 & $\begin{array}{l}\text { Luoyang Ancient City } \\
\text { Protection and } \\
\text { Renovation }\end{array}$ & China & 1.35 & $\mathrm{BOT}+\mathrm{TOT}+\mathrm{ROT}$ & $2 / 3$ & $70 \%$ \\
\hline 15 & $\begin{array}{c}\text { Relocation and Extension } \\
\text { of Chinese Medicine } \\
\text { Hospital in Luxi }\end{array}$ & China & 0.04 & BOT & $1 / 3$ & $70 \%$ \\
\hline
\end{tabular}

This study set the binary threshold of variables according to the content of each factor and the practical condition, which is shown in Table 4.

Tang [118] indicated the optimal equity-debt ratio of PPP projects is $29.17 \%$. However, due to the large investment of PPP projects, high equity-debt ratio leads to high financial pressure to the private sector. Therefore, considering the practical condition, the binary threshold of equity-debt ratio was set to $25 \%(1 / 4)$. Moreover, public and private sectors are the equity investors of PPP projects. Although $50 \%$ is a critical point in the corporate governance in ordinary projects, it is not suitable for PPP projects as this threshold cannot realize the scientific division of value of this outcome. As the role of initiation and supervision of PPP projects, public sector often provides only a small part of funds to support the projects, while the private sector should offer a large part of equity-investment [48]. Considering the data of many PPP projects, the binary threshold of equity-investment ratio of private 
sector was set as $70 \%$. Besides, due to the complexity of critical factors that include several indicators, the binary thresholds were determined by degree instead of specific digit to evaluate the variables reasonably. According to the binary thresholds and data of projects, the binary data sheet of 15 cases is shown in Table 5.

Table 4. Binary threshold of variables.

\begin{tabular}{|c|c|c|}
\hline \multirow{2}{*}{ Variable } & \multicolumn{2}{|c|}{ Value } \\
\hline & 0 & 1 \\
\hline Benefit & Small benefits of project & Large benefits of project \\
\hline Risk & Low-risk in project & High-risk in project \\
\hline Cost & Low cost of project & High cost of project \\
\hline Ability & Weak ability of private sector & Strong ability of private sector \\
\hline Government support & Weak support from government & Strong support from government \\
\hline Project condition & Poor condition of project & Good condition of project \\
\hline External situation & Poor external situation & Good external situation \\
\hline Equity-debt ratio & $<1 / 4$ & $\geq 1 / 4$ \\
\hline $\begin{array}{l}\text { Equity-investment ratio of private } \\
\text { sector }\end{array}$ & $<70 \%$ & $\geq 70 \%$ \\
\hline
\end{tabular}

Table 5. Binary data sheet of 15 cases.

\begin{tabular}{cccccccccc}
\hline \multirow{2}{*}{ Case ID } & \multicolumn{10}{c}{ Variable } \\
\cline { 2 - 9 } & Cost & Benefit & Risk & Ability & $\begin{array}{c}\text { Government } \\
\text { Support }\end{array}$ & $\begin{array}{c}\text { Outside } \\
\text { Situation }\end{array}$ & $\begin{array}{c}\text { Project } \\
\text { Condition }\end{array}$ & $\begin{array}{c}\text { Equity-Debt Equity-Investment Ratio } \\
\text { Ratio }\end{array}$ \\
\hline 1 & 1 & 1 & 1 & 1 & 1 & 1 & 1 & 1 & 1 \\
2 & 0 & 1 & 0 & 1 & 1 & 0 & 1 & 1 & 0 \\
3 & 1 & 1 & 1 & 1 & 1 & 0 & 1 & 1 & 0 \\
4 & 1 & 1 & 1 & 1 & 1 & 1 & 0 & 0 & 1 \\
5 & 0 & 1 & 1 & 0 & 1 & 1 & 0 & 1 & 0 \\
6 & 1 & 0 & 1 & 1 & 1 & 1 & 0 & 1 & 1 \\
7 & 1 & 0 & 0 & 1 & 1 & 1 & 1 & 0 & 1 \\
8 & 0 & 0 & 1 & 1 & 1 & 1 & 1 & 0 & 1 \\
9 & 1 & 0 & 0 & 0 & 1 & 1 & 1 & 0 & 1 \\
10 & 1 & 1 & 1 & 0 & 0 & 0 & 1 & 0 & 1 \\
11 & 1 & 0 & 1 & 1 & 0 & 1 & 0 & 1 & 1 \\
12 & 0 & 1 & 1 & 1 & 0 & 1 & 1 & 1 & 1 \\
13 & 0 & 1 & 0 & 0 & 1 & 1 & 1 & 0 & 1 \\
14 & 1 & 1 & 1 & 1 & 1 & 1 & 1 & 1 & 1 \\
15 & 0 & 0 & 1 & 1 & 1 & 1 & 1 & 1 & 1 \\
\hline
\end{tabular}

\subsection{QCA: Equity-Debt Ratio}

\subsubsection{Qualitative Comparative Analysis}

In this step, the outcome of QCA is the equity-debt ratio of PPP projects. Based on the binary data sheet, the cases that have the same value for each variable were conflated to get the truth table (Table 6).

In the 15 cases, Beijing Metro Line 4 (Case ID = 1) and Luoyang Ancient City Protection and Renovation (Case ID = 14) have the same value for each variable, which means they show the same configuration. Thus, the two cases were combined. Finally, there are 14 different configurations. Analyzing the data of cases that have the same outcome by TOSMANA, this study obtained the formulae in Table 7. In the analysis, the remainders, which mean the areas that the 15 PPP projects cannot cover, were included to assure the reliability of the results [66]. There are nine cases (Case ID $=1,2,3,5,6,11,12,14,15$ ) of result 1 , which means equity-debt ratio of cases is greater than or equal to $1 / 4$, while six cases (Case ID $=4,7,8,9,10,13$ ) show result 0 , that is, equity-debt 
ratio is smaller than $1 / 4$. As shown in Table 7 , there are 14 formulae of result 1 and two formulae representing result 0 .

Table 6. Truth table: equity-debt ratio.

\begin{tabular}{|c|c|c|c|c|c|c|c|c|}
\hline \multirow{2}{*}{ Case ID } & \multicolumn{7}{|c|}{ Variables } & \multirow{2}{*}{$\begin{array}{c}\text { Outcome } \\
\text { Equity-Debt Ratic }\end{array}$} \\
\hline & Cost & Benefit & Risk & Ability & Government Support & Outside Situation & Project Condition & \\
\hline 8 & 0 & 0 & 1 & 1 & 1 & 1 & 1 & 0 \\
\hline 13 & 0 & 1 & 0 & 0 & 1 & 1 & 1 & 0 \\
\hline 2 & 0 & 1 & 0 & 1 & 1 & 0 & 1 & 1 \\
\hline 5 & 0 & 1 & 1 & 0 & 1 & 1 & 0 & 1 \\
\hline 12 & 0 & 1 & 1 & 1 & 0 & 1 & 1 & 1 \\
\hline 15 & 0 & 1 & 1 & 1 & 1 & 1 & 1 & 1 \\
\hline 9 & 1 & 0 & 0 & 0 & 1 & 1 & 1 & 0 \\
\hline 7 & 1 & 0 & 0 & 1 & 1 & 1 & 1 & 0 \\
\hline 11 & 1 & 0 & 1 & 1 & 0 & 1 & 0 & 1 \\
\hline 6 & 1 & 0 & 1 & 1 & 1 & 1 & 0 & 1 \\
\hline 10 & 1 & 1 & 1 & 0 & 0 & 0 & 1 & 0 \\
\hline 3 & 1 & 1 & 1 & 1 & 1 & 0 & 1 & 1 \\
\hline 4 & 1 & 1 & 1 & 1 & 1 & 1 & 0 & 0 \\
\hline 1,14 & 1 & 1 & 1 & 1 & 1 & 1 & 1 & 1 \\
\hline
\end{tabular}

Table 7. Formulae of configurations: equity-debt ratio.

\begin{tabular}{|c|c|c|c|c|c|}
\hline Result & & & Formula & & \\
\hline \multirow{18}{*}{1} & $\begin{array}{l}\text { cost }\{0\} \text { project } \\
\text { condition }\{0\}\end{array}$ & + & $\begin{array}{l}\text { benefit }\{0\} \text { project } \\
\text { condition }\{0\}\end{array}$ & + & $\begin{array}{l}\text { benefit }\{1\} \text { ability }\{1\} \text { project } \\
\text { condition }\{1\}\end{array}$ \\
\hline & (5) & & $(6+11)$ & & $(1,14+2+3+12+15)$ \\
\hline & $\begin{array}{l}\text { cost }\{0\} \text { project } \\
\text { condition }\{0\}\end{array}$ & + & $\operatorname{cost}\{1\}$ benefit $\{0\}$ risk $\{1\}$ & + & $\begin{array}{l}\text { benefit }\{1\} \text { ability }\{1\} \text { project } \\
\text { condition }\{1\}\end{array}$ \\
\hline & (5) & & $(6+11)$ & & $(1,14+2+3+12+15)$ \\
\hline & $\begin{array}{l}\text { benefit }\{0\} \text { project } \\
\text { condition }\{0\}\end{array}$ & + & $\begin{array}{l}\text { ability }\{0\} \text { project } \\
\text { condition }\{0\}\end{array}$ & + & $\begin{array}{l}\text { benefit }\{1\} \text { ability }\{1\} \text { project } \\
\text { condition }\{1\}\end{array}$ \\
\hline & $(6+11)$ & & (5) & & $(1,14+2+3+12+15)$ \\
\hline & $\begin{array}{l}\text { benefit }\{0\} \text { project } \\
\text { condition }\{0\}\end{array}$ & + & $\operatorname{cost}\{0\}$ benefit $\{1\}$ risk $\{1\}$ & + & $\begin{array}{l}\text { benefit }\{1\} \text { ability }\{1\} \text { project } \\
\text { condition }\{1\}\end{array}$ \\
\hline & $(6+11)$ & & $(5+12+15)$ & & $(1,14+2+3+12+15)$ \\
\hline & $\begin{array}{l}\text { benefit }\{0\} \text { project } \\
\text { condition }\{0\}\end{array}$ & + & $\operatorname{cost}\{0\}$ risk $\{1\}$ ability $\{0\}$ & + & $\begin{array}{l}\text { benefit }\{1\} \text { ability }\{1\} \text { project } \\
\text { condition }\{1\}\end{array}$ \\
\hline & $(6+11)$ & & (5) & & $(1,14+2+3+12+15)$ \\
\hline & $\begin{array}{l}\text { benefit }\{0\} \text { project } \\
\text { condition }\{0\}\end{array}$ & + & $\begin{array}{l}\text { benefit }\{1\} \text { ability }\{1\} \text { project } \\
\text { condition }\{1\}\end{array}$ & + & $\begin{array}{c}\text { risk }\{1\} \text { ability }\{0\} \text { government } \\
\text { support }\{1\}\end{array}$ \\
\hline & $(6+11)$ & & $(1,14+2+3+12+15)$ & & (5) \\
\hline & $\begin{array}{l}\text { benefit }\{0\} \text { project } \\
\text { condition }\{0\}\end{array}$ & + & $\begin{array}{l}\text { benefit }\{1\} \text { ability }\{1\} \text { project } \\
\text { condition }\{1\}\end{array}$ & + & $\begin{array}{c}\text { risk }\{1\} \text { ability }\{0\} \text { outside } \\
\text { situation }\{1\}\end{array}$ \\
\hline & $(6+11)$ & & $(1,14+2+3+12+15)$ & & (5) \\
\hline & $\begin{array}{l}\text { ability }\{0\} \text { project } \\
\text { condition }\{0\}\end{array}$ & + & $\operatorname{cost}\{1\}$ benefit $\{0\}$ risk $\{1\}$ & + & $\begin{array}{l}\text { benefit }\{1\} \text { ability }\{1\} \text { project } \\
\text { condition }\{1\}\end{array}$ \\
\hline & (5) & & $(6+11)$ & & $(1,14+2+3+12+15)$ \\
\hline & $\operatorname{cost}\{0\}$ benefit $\{1\}$ risk $\{1\}$ & + & $\operatorname{cost}\{1\}$ benefit $\{0\}$ risk $\{1\}$ & + & $\begin{array}{l}\text { benefit }\{1\} \text { ability }\{1\} \text { project } \\
\text { condition }\{1\}\end{array}$ \\
\hline & $(5+12+15)$ & & $(6+11)$ & & $(1,14+2+3+12+15)$ \\
\hline
\end{tabular}


Table 7. Cont.

\begin{tabular}{|c|c|c|c|c|c|}
\hline Result & & & Formula & & \\
\hline & $\operatorname{cost}\{0\}$ risk $\{1\}$ ability $\{0\}$ & + & $\operatorname{cost}\{1\}$ benefit $\{0\}$ risk $\{1\}$ & + & $\begin{array}{l}\text { benefit }\{1\} \text { ability }\{1\} \text { project } \\
\text { condition }\{1\}\end{array}$ \\
\hline & (5) & & $(6+11)$ & & $(1,14+2+3+12+15)$ \\
\hline & $\operatorname{cost}\{1\}$ benefit $\{0\}$ risk $\{1\}$ & + & $\begin{array}{l}\text { benefit }\{1\} \text { ability }\{1\} \text { project } \\
\text { condition }\{1\}\end{array}$ & + & $\begin{array}{c}\text { risk }\{1\} \text { ability }\{0\} \text { government } \\
\text { support }\{1\}\end{array}$ \\
\hline & $(6+11)$ & & $(1,14+2+3+12+15)$ & & $(5)$ \\
\hline & $\operatorname{cost}\{1\}$ benefit $\{0\}$ risk $\{1\}$ & + & $\begin{array}{l}\text { benefit }\{1\} \text { ability }\{1\} \text { project } \\
\text { condition }\{1\}\end{array}$ & + & $\begin{array}{l}\text { risk }\{1\} \text { ability }\{0\} \text { outside } \\
\text { situation }\{1\}\end{array}$ \\
\hline & $(6+11)$ & & $(1,14+2+3+12+15)$ & & (5) \\
\hline \multirow{4}{*}{0} & $\begin{array}{l}\text { benefit }\{0\} \text { project } \\
\text { condition }\{1\}\end{array}$ & + & $\begin{array}{l}\text { ability }\{0\} \text { project } \\
\text { condition }\{1\}\end{array}$ & + & $\begin{array}{l}\text { cost }\{1\} \text { benefit }\{1\} \text { project } \\
\text { condition }\{0\}\end{array}$ \\
\hline & $(7+8+9)$ & & $(9+10+13)$ & & $(4)$ \\
\hline & $\begin{array}{l}\text { benefit }\{0\} \text { project } \\
\text { condition }\{1\}\end{array}$ & + & $\begin{array}{l}\text { ability }\{0\} \text { project } \\
\text { condition }\{1\}\end{array}$ & + & $\begin{array}{l}\text { benefit }\{1\} \text { ability }\{1\} \text { project } \\
\text { condition }\{0\}\end{array}$ \\
\hline & $(7+8+9)$ & & $(9+10+13)$ & & (4) \\
\hline
\end{tabular}

\subsubsection{Minimal Formula: Equity-Debt Ratio}

After the Boolean minimization of these formulae, the intersection of formulae from the same result, that is, the minimal formula of each result, is shown in Equations (1) and (2).

1) Result 1: equity-debt ratio $\leq 1 / 4$

$$
\begin{gathered}
\operatorname{cost}\{0\} \text { benefit }\{1\} \text { risk }\{1\} \text { ability }\{0\} \text { government support }\{1\} \text { outside situation }\{1\} \text { project } \\
\text { condition }\{0\}+\operatorname{cost}\{1\} \text { benefit }\{0\} \text { risk }\{1\} \text { project condition }\{0\}+ \\
\text { benefit }\{1\} \text { ability }\{1\} \text { project condition }\{1\}
\end{gathered}
$$

Equation (1) indicates that result 1 will happen under three circumstances.

(1) PPP projects that have low costs and high benefits but high risks with strong support of government, good external situation and private sector whose ability is weak

Low costs and high benefits can assure the stable cash flow which brings reasonable return to investors and creditors and achieves the successful operation of PPP projects. Moreover, strong support from government and good external situation are important aids for projects to improve capabilities, finish standard operation and realize expected targets. Under the combination of the four factors, the investors can keep confidence in the future development of PPP projects and raise the expected rate of investment even though the project has high-level risk and the private sector has weak ability. Thus, investors will offer a larger proportion of equity capital to obtain more benefits and contribute to the development of industry, region and society.

(2) PPP projects with high costs, high risks, low benefits and bad project condition

Under this condition, the future development of PPP project is not optimistic, which means it cannot attract ample funds to maintain. Therefore, investors will increase the equity-debt ratio properly. More equity capital can improve the financial ability of projects and reduce the worries of financial institutions to support the successful implementation of PPP projects. In general, public sector will invest more funds to incentivize the investment of private sector and financiers to achieve the long-term healthy operation of PPP projects. 
(3) PPP projects that have high benefits, good project condition and private sector with strong abilities

Combined with the three good conditions of PPP projects, investors will have positive prediction of the results of PPP projects. Thus, they are willing to invest more funds to obtain benefits for companies and contribute to the development of industry, region and society.

2) Result 0: equity-debt ratio $<1 / 4$

$$
\begin{aligned}
& \text { benefit }\{0\} \text { project condition }\{1\}+\text { ability }\{0\} \text { project condition }\{1\}+ \\
& \text { cost }\{1\} \text { benefit }\{1\} \text { ability }\{1\} \text { project condition }\{0\}
\end{aligned}
$$

Equation (2) shows the minimal formula of result 0 . There are also three situations:

(1) PPP projects with low benefits and good project condition

Low expected benefits make the investment behaviors of investors more deliberate, which means equity-investment will decrease. Meanwhile, good project condition can support the stability of cash flow to promote the healthy life-cycle operation of PPP projects and increase the stability of repayments of debt funds. Therefore, financial institutions are likely to provide more debt funds, which increases the equity-debt ratio.

(2) PPP projects with good project condition but private sector whose abilities is weak

Good project condition, such as strong profitability and high credit rating, can enhance the confidence of creditors, encouraging them to provide high proportion of debt funds. Moreover, the private sector that has weak abilities may face many difficulties during the implementation of projects. Therefore, the private sector will be more cautious about the equity-investment, thus decreasing the equity-debt ratio.

(3) PPP projects that have high benefits and private sector with strong abilities but high costs and bad project condition

High benefits and the private sector that has strong abilities can assure the positive expectation of projects. Therefore, although the projects have high costs and some bad conditions, financial institutions can keep confidence in the expected long-term operation of projects. Thus, they will provide more funds to decrease the equity-debt ratio.

\subsection{QCA: Equity-Investment Ratio of Private Sector}

\subsubsection{Qualitative Comparative Analysis}

Making equity-investment ratio of private sector as the outcome, 13 different configurations are shown in Table 8. Beijing Metro Line 4 (Case ID =1) and Luoyang Ancient City Protection and Renovation (Case ID $=14$ ) have the same configuration. Sludge Treatment Project in Sudbury (Case ID = 8) and Relocation and Extension of Chinese Medicine Hospital in Luxi (Case ID = 15) also show the same value of each variable and outcome.

The configurations can be expressed as formulae, as shown in Table 9. Result 1 means the equity-investment ratio of private sector is larger than or equal to $70 \%$ (Case ID $=1,4,5,7,8,9,10$, $12,13,14,15)$, while result 0 shows the equity-investment ratio of private sector is smaller than $70 \%$ (Case ID $=2,3,6,11$ ). There are 11 equations of result 1 and four formulae of result 0 (Table 9). 
Table 8. Truth table: equity-investment ratio of private sector.

\begin{tabular}{ccccccccc}
\hline Case ID & \multicolumn{7}{c}{ Variables } & Outcome \\
\cline { 2 - 8 } & Cost & Benefit & Risk & Ability & $\begin{array}{c}\text { Government } \\
\text { Support }\end{array}$ & $\begin{array}{c}\text { Outside } \\
\text { Situation }\end{array}$ & $\begin{array}{c}\text { Project } \\
\text { Condition }\end{array}$ & $\begin{array}{c}\text { Equity-Investment } \\
\text { Ratio of Private Sector }\end{array}$ \\
\hline 8,15 & 0 & 0 & 1 & 1 & 1 & 1 & 1 & 1 \\
13 & 0 & 1 & 0 & 0 & 1 & 1 & 1 & 1 \\
2 & 0 & 1 & 0 & 1 & 1 & 0 & 1 & 0 \\
5 & 0 & 1 & 1 & 0 & 1 & 1 & 0 & 1 \\
12 & 0 & 1 & 1 & 1 & 0 & 1 & 1 & 1 \\
9 & 1 & 0 & 0 & 0 & 1 & 1 & 1 & 1 \\
7 & 1 & 0 & 0 & 1 & 1 & 1 & 1 & 0 \\
11 & 1 & 0 & 1 & 1 & 0 & 1 & 0 & 1 \\
6 & 1 & 0 & 1 & 1 & 1 & 1 & 0 & 0 \\
10 & 1 & 1 & 1 & 0 & 0 & 0 & 1 & 1 \\
3 & 1 & 1 & 1 & 1 & 1 & 0 & 1 & 1 \\
4 & 1 & 1 & 1 & 1 & 1 & 1 & 0 & 1 \\
1,14 & 1 & 1 & 1 & 1 & 1 & 1 & 1 & 0 \\
\hline
\end{tabular}

Table 9. Formulae of configurations: equity-investment ratio of private sector.

\begin{tabular}{|c|c|c|c|c|c|}
\hline Result & & & Formulae & & \\
\hline \multirow{18}{*}{1} & ability $\{0\}$ & + & $\begin{array}{l}\text { benefit }\{0\} \text { project } \\
\text { condition }\{1\}\end{array}$ & + & benefit $\{1\}$ outside situation $\{1\}$ \\
\hline & $(5+9+10+13)$ & & $(7+8,15+9)$ & & $(1,14+4+5+12+13)$ \\
\hline & ability $\{0\}$ & + & $\begin{array}{l}\text { benefit }\{1\} \text { outside } \\
\text { situation }\{1\}\end{array}$ & + & $\begin{array}{l}\text { outside situation }\{1\} \text { project } \\
\text { condition }\{1\}\end{array}$ \\
\hline & $(5+9+10+13)$ & & $(1,14+4+5+12+13)$ & & $(1,14+7+8,15+9+12+13)$ \\
\hline & ability $\{0\}$ & + & $\begin{array}{l}\text { benefit }\{1\} \text { project } \\
\text { condition }\{0\}\end{array}$ & + & $\begin{array}{l}\text { outside situation }\{1\} \text { project } \\
\text { condition }\{1\}\end{array}$ \\
\hline & $(5+9+10+13)$ & & $(4+5)$ & & $(1,14+7+8,15+9+12+13)$ \\
\hline & $\begin{array}{l}\text { benefit }\{0\} \text { project } \\
\text { condition }\{1\}\end{array}$ & + & $\begin{array}{l}\text { benefit }\{1\} \text { government } \\
\text { support }\{0\}\end{array}$ & + & benefit $\{1\}$ outside situation $\{1\}$ \\
\hline & $(7+8,15+9)$ & & $(10+12)$ & & $(1,14+4+5+12+13)$ \\
\hline & $\begin{array}{l}\text { benefit }\{0\} \text { project } \\
\text { condition }\{1\}\end{array}$ & + & $\begin{array}{l}\text { benefit }\{1\} \text { outside } \\
\text { situation }\{1\}\end{array}$ & + & $\begin{array}{c}\text { government support }\{0\} \text { outside } \\
\text { situation }\{0\}\end{array}$ \\
\hline & $(7+8,15+9)$ & & $(1,14+4+5+12+13)$ & & $(10)$ \\
\hline & $\begin{array}{l}\text { benefit }\{0\} \text { project } \\
\text { condition }\{1\}\end{array}$ & + & $\begin{array}{l}\text { benefit }\{1\} \text { outside } \\
\text { situation }\{1\}\end{array}$ & + & $\begin{array}{c}\text { government support }\{0\} \text { project } \\
\text { condition }\{1\}\end{array}$ \\
\hline & $(7+8,15+9)$ & & $(1,14+4+5+12+13)$ & & $(1+12)$ \\
\hline & $\begin{array}{l}\text { benefit }\{1\} \text { government } \\
\text { support }\{0\}\end{array}$ & + & $\begin{array}{l}\text { benefit }\{1\} \text { outside } \\
\text { situation }\{1\}\end{array}$ & + & $\begin{array}{l}\text { outside situation }\{1\} \text { project } \\
\text { condition }\{1\}\end{array}$ \\
\hline & $(10+12)$ & & $(1,14+4+5+12+13)$ & & $(1,14+7+8,15+9+12+13)$ \\
\hline & $\begin{array}{l}\text { benefit }\{1\} \text { government } \\
\text { support }\{0\}\end{array}$ & + & $\begin{array}{l}\text { benefit }\{1\} \text { project } \\
\text { condition }\{0\}\end{array}$ & + & $\begin{array}{l}\text { outside situation }\{1\} \text { project } \\
\text { condition }\{1\}\end{array}$ \\
\hline & $(10+12)$ & & $(4+5)$ & & $(1,14+7+8,15+9+12+13)$ \\
\hline & $\begin{array}{l}\text { benefit }\{1\} \text { outside } \\
\text { situation }\{1\}\end{array}$ & + & $\begin{array}{l}\text { government } \\
\text { support }\{0\} \text { outside } \\
\text { situation }\{0\}\end{array}$ & + & $\begin{array}{l}\text { outside situation }\{1\} \text { project } \\
\text { condition }\{1\}\end{array}$ \\
\hline & $(1,14+4+5+12+13)$ & & $(10)$ & & $(1,14+7+8,15+9+1+13)$ \\
\hline
\end{tabular}


Table 9. Cont.

\begin{tabular}{|c|c|c|c|c|c|}
\hline Result & & & Formulae & & \\
\hline & $\begin{array}{l}\text { benefit }\{1\} \text { outside } \\
\text { situation }\{1\}\end{array}$ & + & $\begin{array}{l}\text { government } \\
\text { support }\{0\} \text { project } \\
\text { condition }\{1\}\end{array}$ & + & $\begin{array}{l}\text { outside situation }\{1\} \text { project } \\
\text { condition }\{1\}\end{array}$ \\
\hline & $(1,14+4+5+12+13)$ & & $(10+12)$ & & $(1,14+7+8,15+9+12+13)$ \\
\hline & $\begin{array}{l}\text { benefit }\{1\} \text { project } \\
\text { condition }\{0\}\end{array}$ & + & $\begin{array}{l}\text { government } \\
\text { support }\{0\} \text { outside } \\
\text { situation }\{0\}\end{array}$ & + & $\begin{array}{l}\text { outside situation }\{1\} \text { project } \\
\text { condition }\{1\}\end{array}$ \\
\hline & $(4+5)$ & & (10) & & $(1,14+7+8,15+9+12+13)$ \\
\hline & $\begin{array}{l}\text { benefit }\{1\} \text { project } \\
\text { condition }\{0\}\end{array}$ & + & $\begin{array}{l}\text { government } \\
\text { support }\{0\} \text { project } \\
\text { condition }\{1\}\end{array}$ & + & $\begin{array}{l}\text { outside situation }\{1\} \text { project } \\
\text { condition }\{1\}\end{array}$ \\
\hline & $(4+5)$ & & $(10+12)$ & & $(1,14+7+8,15+9+12+13)$ \\
\hline \multirow{8}{*}{0} & $\begin{array}{c}\text { benefit }\{0\} \text { project } \\
\text { condition }\{0\}\end{array}$ & + & $\begin{array}{l}\text { ability }\{1\} \text { outside } \\
\text { situation }\{0\}\end{array}$ & & \\
\hline & $(6+11)$ & & $(2+3)$ & & \\
\hline & $\begin{array}{l}\text { benefit }\{0\} \text { project } \\
\text { condition }\{0\}\end{array}$ & + & $\begin{array}{l}\text { government } \\
\text { support }\{1\} \text { outside } \\
\text { situation }\{0\}\end{array}$ & & \\
\hline & $(6+11)$ & & $(2+3)$ & & \\
\hline & $\begin{array}{l}\text { ability }\{1\} \text { outside } \\
\text { situation }\{0\}\end{array}$ & + & $\operatorname{cost}\{1\}$ benefit $\{0\}$ risk $\{1\}$ & & \\
\hline & $(2+3)$ & & $(6+11)$ & & \\
\hline & $\begin{array}{c}\text { government } \\
\text { support }\{1\} \text { outside } \\
\text { situation }\{0\}\end{array}$ & + & $\operatorname{cost}\{1\}$ benefit $\{0\}$ risk $\{1\}$ & & \\
\hline & $(2+3)$ & & $(6+11)$ & & \\
\hline
\end{tabular}

\subsubsection{Minimal Formula: Equity-investment Ratio of Private Sector}

After the Boolean minimization of formulae, the minimal formulae are shown as Equations (3) and (4).

1) Result 1: equity-investment ratio of private sector $\geq 75 \%$

benefit $\{1\}$ ability $\{0\}$ government support $\{0\}$ project condition $\{1\}+$ benefit $\{1\}$ outside situation $\{1\}+$ outside situation $\{1\}$ project condition $\{1\}$

As shown in Equation (3), there are three configurations of result 1.

(1) PPP projects that have good conditions and high benefits but weak government support and private sector whose ability is weak

Projects with high benefits and good project conditions can strengthen confidences of private sector in the future development of projects. Thus, they will have high expectation of the rate of return and healthy and sustainable operation. Under such favorable condition, even though the government support and private sector's ability are weak, the development of PPP projects will not be weakened. Thus, the private sector is willing to invest more equity funds. 
(2) PPP projects with high benefits and good project conditions

The high rate of return of private sector as well as other targets of projects can be achieved in this kind of PPP projects, which means the PPP projects can be finished successfully with great possibility. Thus, the private sector is likely to invest more equity funds to gain more benefits in the PPP projects.

(3) PPP projects with good external situation and project condition

Good project condition can promote the achievement of targets and good external situation can strongly support the success of projects. Therefore, the long-term healthy operation of PPP projects can be assured, which can attract private sector to provide more funds.

2) Result 0: equity-investment ratio of private sector $<75 \%$

$$
\begin{gathered}
\operatorname{cost}\{1\} \text { benefit }\{0\} \text { risk }\{1\} \text { project condition }\{0\}+\text { ability }\{1\} \text { government } \\
\text { support }\{1\} \text { outside situation }\{0\}
\end{gathered}
$$

There are two situations of result 0 shown in Equation (4).

(1) PPP projects with high costs, high risks, low benefits and bad project condition

There are obvious disadvantages of this kind of PPP projects, which will impact the confidence of participants. Thus, there may be many difficulties during the implementation of PPP projects. Public sector will increase the equity-investment ratio to attract the investment from the private sector and financial institution to promote the development of PPP projects.

(2) PPP projects with strong government support and abilities of the private sector but bad external situation

The finance of PPP projects follows the trends and conditions of external situation, which impact the investment behavior of the private sector. Bad external situation will lead the private sector to decrease investments to isolate risks, while the public sector will increase the investments and provide other support measures to incentivize the investment of the private sector and financial institution.

\subsection{Discussion of the Results}

First, benefit is the most important factor, which is accordance with the result of literature analysis. Under different configurations, this factor is the core concern of all participants of PPP projects [129]. The private sector and financial institution care more about the economic benefits [48,79], while the public interest is also essential indicator including social and environmental benefits. The capital structure that considers both the economic and non-economic benefits can promote the healthy development of PPP projects, industry, region and society [92].

Second, project condition shows salient importance. Different project condition will impact the predictions of projects and change the participants' investment decisions. Good profitability of projects [80], project type that can attract ample funds [85], proper investment scale that is neither very large to bring financial burden nor very small to obtain insufficient support [90], and good credit rating can bolster the confidence of investors and financiers to increase the equity-investment ratio of private sector and decrease the equity-debt ratio by attracting more debt funds [55]. Meanwhile, good project condition contributes to the life-cycle success of PPP projects and healthy development of industry, region and society.

Moreover, external situation and cost are embodied in the formulae. Both the investment behavior of private sector and financial institution have close relationship with the external situation $[23,91,94,102]$. With favorable capital market, industry condition, laws and regulations, private sector as well as financial institution will be willing to provide more funds. Thus, the equity-debt 
ratio and equity-investment ratio of private sector will increase. At the same time, the minimization of costs is an important target when determining the capital structure [54,84]. The intangible costs should be concerned as well as economic costs to promote the life-cycle healthy operation of PPP projects and not bring about bad impact on the development of industry, region and society [87].

Besides, the ability of private sector and government support should be considered. The support measures of government can strengthen the projects to attract more funds and assure the successful operation of PPP projects [52,86]. Government's financial support, equity incentive and preferential policies encourage the private sector and financial institution to offer capital $[105,126]$. Additionally, the supervision of standard operation directly influences the life-cycle operation and result of PPP projects. Meanwhile, the ability of private sector is an essential indicator that influences the investment decision of each participant $[131,132]$. Strong abilities of private sector help the projects to realize targets at each stage and promote the healthy and successful life-cycle operation. Therefore, strong abilities of private sector can attract more funds from financiers to decrease the equity-debt ratio.

However, it is not in accordance with the result of literature analysis that risk does not show great importance in the formulae. This is because risk is throughout the life-cycle of PPP projects and has deep correlation with the other six factors [93]. Even though risk does not show great importance in the result of QCA, the variations of other factors will lead to the dynamic adjustment of risk identification, allocation and control [137]. Therefore, the risk factor should be analyzed comprehensively combined with other factors to reasonably predict the costs and result of risk control and its influences of long-term development of PPP projects to select scientific capital structure.

\section{Conclusions}

This study investigated the critical factors influencing the capital structure of PPP projects from a sustainability perspective. The results of literature analysis showed that there were seven critical factors: benefit, cost, ability, risk, project condition, government support and external situation. Moreover, all the seven factors were related to sustainability. The public interest, social and environment costs, life-cycle management ability, standard operation, project type, capital market, industry situation and all indicators of risk factor should be emphasized from a sustainability perspective. Then, the results of QCA clearly showed the relationship between factors and the capital structure of PPP project.

The major implications are: (i) as benefit was found to be the most important factor, both public interests and the economic benefits should be considered; (ii) the profitability, investment size and credit rating are essential economic factors, while the development of industry should be assessed according to project types; (iii) in addition to the traditional economic costs, social and environmental costs have critical impacts and are thus worth attention; (iv) both investors and financiers have concerns regarding the capital market, industry condition, laws and regulations to achieve the capital structure that not only provides ample funds but also follows the trends of industry and society; (v) the life-cycle management ability of the private sector can strongly influence the long-term operation of PPP projects, while the financing, construction and operation abilities impact the specific phrases in the life cycle; and (vi) support from the government not only incentivizes the investment of private sector and financing institutions, but also promotes the standard operation to assure the long-term healthy operation of PPP projects. Thus, considering these factors, proper capital structure can be selected to provide ample funds for PPP projects and promote the long-term healthy operation of projects and future development of the industry, region and society.

From the theoretical perspective, this study not only enriches the research of the capital structure of PPP projects, but also provides new idea for the combination of sustainability and PPP projects. In practice, the findings can offer references for the solution of unreasonable capital structure in PPP projects and help the participants to think more comprehensively. Besides, the research expands the application of sustainability on the practice of PPP projects to achieve the selection of proper capital structure and promote healthy development of PPP projects. 
Despite achievement of the research objectives, there are still some limitations. Due to the complexity of capital structure of PPP projects, this study selected two indicators as dependent variables. In the future, the deep analysis of capital structure can be conducted. Other aspects of the capital structure will be analyzed as the dependent variables, such as the source and proportion of debt funds, to investigate the capital structure comprehensively. Moreover, this paper did not fully consider the different role of public sector and private sector, which may impact the sustainability of PPP projects and participation of private sector. Future study will pay more attention to the differences to achieve a more comprehensive result. Additionally, how the leverage incentives of the public sector to involve the private company as well as private sector to participate the PPP project was not discussed in this study. In the future, the impacts of different capital structure on the behaviors of public sector and private sector will be analyzed. Besides, considering the character of different fields or countries, future study may focus on one specific area or country to make deep and targeted analysis.

Author Contributions: J.D. and H.W. conceived and designed the study; H.W. analyzed the data and wrote the paper; and X.Z. and J.D. reviewed and revised the original draft.

Funding: This research received funding from Humanities and Social Science Foundation from the Ministry of Education, People's Republic of China [15YJAZH012].

Acknowledgments: This study was supported by Humanities and Social Science Foundation from the Ministry of Education, People's Republic of China [15YJAZH012].

Conflicts of Interest: The authors declare no conflict of interest. The founding sponsors had no role in the design of the study; in the collection, analyses, and interpretation of data; in the writing of the manuscript, and in the decision to publish the results.

\section{References}

1. World Bank; Asian Development Bank; Inter-American Development Bank. Public Private Partnerships Reference Guide; 2014 International Bank for Reconstruction and Development: Washington, DC, USA, 2014.

2. Zhang, S.; Chan, A.P.C.; Feng, Y.; Duan, H.; Ke, Y. Critical review on PPP Research-A search from the Chinese and International Journals. Int. J. Proj. Manag. 2016, 34, 597-612. [CrossRef]

3. Hwang, B.-G.; Zhao, X.; Gay, M.J.S. Public private partnership projects in Singapore: Factors, critical risks and preferred risk allocation from the perspective of contractors. Int. J. Proj. Manag. 2013, 31, 424-433. [CrossRef]

4. Zhang, X. Financial Viability Analysis and Capital Structure Optimization in Privatized Public Infrastructure Projects. J. Constr. Eng. Manag. 2005, 131, 656-668. [CrossRef]

5. Hu, X.; Liu, Z. Debt in the name of equity in the implementation. Legal Daily, 2 March 2017. (In Chinese)

6. Wang, Y. Analysis of privatization mode of public utilities-an empirical study based on Hangzhou Bay Sea-crossing Bridge. J. Sichuan Admin. Coll. 2010, 1, 98-101. (In Chinese) [CrossRef]

7. Chang, L.; Chen, P. BOT Financial Model: Taiwan High Speed Rail Case. J. Constr. Eng. Manag. 2001, 127, 214-222. [CrossRef]

8. Anguera, R. The Channel Tunnel-An ex post economic evaluation. Transp. Res. Part A Policy Pract. 2006, 40, 291-315. [CrossRef]

9. European Commission. Resource Book on PPP Case Studies; European Commission: Brussels, Belgium, 2004.

10. United Nations Brundtland Commission. World Commission on Environment and Development (WCED): Our Common Future; Oxford University Press: Oxford, UK, 1987.

11. Kates, R.W.; Parris, T.M.; Leiserowitz, A.A. What is sustainable development? Goals, indicators, values and practice. Environ. Sci. Policy Sustain. Dev. 2005, 47, 8-21.

12. United Nations. Transforming Our World: The 2030 Agenda for Sustainable Development; United Nations: New York, NY, USA, 2014.

13. United Nations Economic Commission for Europe. List of PPP Standards in Support of the United Nations Sustainable Development Goals; United Nations Economic Commission for Europe: Geneva, Switzerland, 2015.

14. Yao, X. Government Supervision on the Opration Stage of Urban Infrastructure under PPP Mode. Master's Thesis, Anhui Jianzhu University, Anhui, China, 2016. (In Chinese) 
15. Daly, H.E. Toward some operational principles of sustainable development. Ecol. Econ. 1990, 2, 1-6. [CrossRef]

16. Kuhlman, T.; Farrington, J. What is Sustainability? Sustainability 2010, 2, 3436-3448. [CrossRef]

17. Imran, S.; Alam, K.; Beaumont, N. Reinterpreting the Definition of Sustainable Development for a More Ecocentric Reorientation. Sustain. Dev. 2014, 22, 134-144. [CrossRef]

18. Manderson, A.K. A Systems Based Framework to Examine The Multi-contextural Application of the Sustainability Concept. Environ. Dev. Sustain. 2006, 8, 85-97. [CrossRef]

19. Ostrom, E. A General Framework for Analyzing Sustainability of Social-Ecological Systems. Science 2009, 325, 419-422. [CrossRef] [PubMed]

20. Villalba-Romero, F.; Liyanage, C.; Roumboutsos, A. Sustainable PPPs: A comparative approach for road infrastructure. Case Stud. Transp. Policy 2015, 3, 243-250. [CrossRef]

21. Xiong, W.; Chu, D. Theory and Practice of sustainability-oriented Public Private Partnership. Tongji Univ. J. Soc. Sci. Sect. 2017, 28, 78-84. (In Chinese)

22. Zhang, P.; Wang, L.; Zhang, P.; Wu, Y. Sustainability Performance Evaluation Model on PPP Projects. Technoecon. Manag. Res. 2017, 14-17. (In Chinese)

23. Atmo, G.; Florence Yean Yng, L.; Carlo, D.; Duffield, C. Improving investment sustainability for PPP power projects in emerging economies. Built Environ. Proj. Asset Manag. 2014, 4, 335-351. [CrossRef]

24. Zhou, M. Sustainability Post Evaluation of PPP Projects. Master's Thesis, Dongbei University of Finance and Economics, Dalian, China, 2016. (In Chinese)

25. Kumaraswamy, M.; Anvuur, A.; Rahamn, M. Balancing contractual and relational approaches for PPP success and sustainability. In Proceedings of the Conference on Public Private Partnerships: Opportunities and Challenges, Hong Kong, China, 22 February 2005.

26. Ye, X.; Deng, Y. Research on the Approach to Realize Sustainability of PPP Infrastructure Project from the Perspective of Partnership. Sci. Technol. Manag. Res. 2014, 12, 189-193. (In Chinese)

27. Myers, S.C. The Capital Structure Puzzle. J. Financ. 1983, 39, 575-592. [CrossRef]

28. Durand, D. Costs of debt and equity funds for business: Trends and problems of measurement. In Conference on Research in Business Finance; NBER: Cambridge, MA, USA, 1952.

29. Modigliani, F.; Miller, M.H. The cost of capital, corporation finance and the theory of investment. Am. Econ. Rev. 1958, 48, 261-297.

30. Rose, J.R. The Cost of Capital, Corporation Finance, and The theroy of Investment. Am. Econ. Rev. 1959, 49, 638-639.

31. Modigliani, F.; Miller, M.H. Corporate income taxes and the cost of capital: A correction. Am. Econ. Rev. 1963, 53, 433-443.

32. Kraus, A.; Litzenberger, R.H. A state-preference model of optimal financial leverage. J. Financ. 1973, 28, 911-922. [CrossRef]

33. Myers, S.C.; Majluf, N.S. Corporate financing and investment decisions when firms have information that investors do not have. J. Financ. Econ. 1984, 13, 187-221. [CrossRef]

34. William, H.M.; Michael, J. Theory of the firm: Managerial behavior, agency costs and ownership structure. J. Financ. Econ. 1976, 3, 304-360.

35. Ross, S.A. The determination of financial structure: The incentive-signalling approach. Bell J. Econ. 1977, 8, 23-40. [CrossRef]

36. Harris, M.; Raviv, A. Corporate governance: Voting rights and majority rules. J. Financ. Econ. 1988, 20, 203-235. [CrossRef]

37. Stulz, R. Managerial control of voting rights: Financing policies and the market for corporate control. J. Financ. Econ. 1988, 20, 25-54. [CrossRef]

38. Aghion, P.; Bolton, P. An Incomplete Contracts Approach to Financial Contracting. Rev. Econ. Stud. 1992, 59, 473-494. [CrossRef]

39. Brander, J.A.; Lewis, T.R. Oligopoly and financial structure the limited liability effect. Am. Econ. Rev. 1986, 76, 956-970.

40. Onaolapo, A.A.; Kajola, S.O.; Nwidobie, M.B. Determinants of capital structure: A study of Nigerian quoted companies. Eur. J. Bus. Manag. 2015, 7, 170-183.

41. Feld, L.P.; Heckemeyer, J.H.; Overesch, M. Capital structure choice and company taxation: A meta-study. J. Bank. Financ. 2013, 37, 2850-2866. [CrossRef] 
42. Robb, A.M.; Robinson, D.T. The Capital Structure Decisions of New Firms. Rev. Financ. Stud. 2014, 27, 153-179. [CrossRef]

43. Ampenberger, M.; Schmid, T.; Achleitner, A.-K.; Kaserer, C. Capital structure decisions in family firms: Empirical evidence from a bank-based economy. Rev. Manag. Sci. 2011, 7, 247-275. [CrossRef]

44. Frank, M.Z.; Shen, T. Investment and the weighted average cost of capital. J. Financ. Econ. 2016, 119, 300-315. [CrossRef]

45. Magni, C.A. Investment, financing and the role of ROA and WACC in value creation. Eur. J. Oper. Res. 2015, 244, 855-866. [CrossRef]

46. Lintner, J. The valuation of risk assets and the selection of risky investment in stock portfolios and capital budgets. Rev. Econ. Stat. 1965, 47, 13-37. [CrossRef]

47. Vecchi, V.; Hellowell, M.; Gatti, S. Does the private sector receive an excessive return from investments in health care infrastructure projects? Evidence from the UK. Health Policy 2013, 110, 243-270. [CrossRef] [PubMed]

48. Sharma, D.; Cui, Q.; Chen, L.; Lindly, J. Balancing Private and Public Interests in Public-Private Partnership Contracts Through Optimization of Equity Capital Structure. Transp. Res. Rec. J. Transp. Res. Board 2010, 2151, 60-66. [CrossRef]

49. Sheng, H.; Wei, L.; ShouQing, W.; Yongjian, K. PPP Project Risk Relationships based on the Interpretive Structure Model. Int. J. Adv. Inf. Sci. Serv. Sci. 2013, 5, 618-627. [CrossRef]

50. Toms, S.; Beck, M.; Asenova, D. Accounting, regulation and profitability: The case of PFI hospital refinancing. Crit. Perspect. Account. 2011, 22, 668-681. [CrossRef]

51. Daube, D.; Vollrath, S.; Alfen, H.W. A comparison of Project Finance and the Forfeiting Model as financing forms for PPP projects in Germany. Int. J. Proj. Manag. 2008, 26, 376-387. [CrossRef]

52. Tao, P.; Ji, W. Cost-Benefit Analysis of PPP Project Financing Based on the Government's Position. ICCREM, 11-12 August 2015.

53. Demirag, I.; Khadaroo, I.; Stapleton, P. A changing market for PFI financing: Evidence from the financiers. Account. Forum 2015, 39, 188-200. [CrossRef]

54. Yun, S.; Han, S.H.; Kim, H.; Ock, J.H. Capital structure optimization for build-operate-transfer (BOT) projects using a stochastic and multi-objective approach. Can. J. Civ. Eng. 2009, 36, 777-790. [CrossRef]

55. Demirag, I.; Khadaroo, I.; Stapleton, P.; Stevenson, C. Risks and the financing of PPP: Perspectives from the financiers. Br. Account. Rev. 2011, 43, 294-310. [CrossRef]

56. Cuthbert, J.; Cuthbert, M. Why IRR is an inadequate indicator of costs and returns in relation to PFI schemes. Crit. Perspect. Account. 2012, 23, 420-433. [CrossRef]

57. Cuthbert, J.R.; Magni, C.A. Measuring the inadequacy of IRR in PFI schemes using profitability index and AIRR. Int. J. Prod. Econ. 2016, 179, 130-140. [CrossRef]

58. Ramsey, D.; Asmar, M.E. Analysis of funding sources for DBF PPP projects in the US transportation sector: An ongoing national study. In Proceedings of the 2016 Construction Research Congress (CRC 2016), San Juan, Puerto Rico, 31 May-2 June 2016.

59. Shuai, L.; Hubo, C. Government incentive impacts on private investment behaviors under demand uncertainty. Transp. Res. Part E Logist. Transp. Rev. 2017, 101, 115-129. [CrossRef]

60. Bowen, G.A. Document analysis as a qualitative research method. Qual. Res. J. 2009, 9, 27-40. [CrossRef]

61. Chan, A.P.C.; Lam, P.T.I.; Chan, D.W.M.; Cheung, E.; Ke, Y. Critical Success Factors for PPPs in Infratructure Developments: Chinese Perspective. J. Constr. Eng. Manag. 2010, 136, 484-494. [CrossRef]

62. Zou, W.; Kumaraswamy, M.; Chung, J.; Wong, J. Identifying the critical success factors for relationship management in PPP projects. Int. J. Proj. Manag. 2014, 32, 265-274. [CrossRef]

63. Soomro, M.A.; Zhang, X. Roles of Private-Sector Partners in Transportation Public-Private Partnership Failures. J. Manag. Eng. 2015, 31, 4014056. [CrossRef]

64. Schneider, C.Q.; Wagemann, C. Reducing complexity in Qualitative Comparative Analysis (QCA): Remote and proximate factors and the consolidation of democracy. Eur. J. Polit. Res. 2006, 45, 751-786. [CrossRef]

65. Marx, A.; Rihoux, B.; Ragin, C. The origins, development, and application of Qualitative Comparative Analysis: The first 25 years. Eur. Polit. Sci. Rev. 2013, 6, 115-142. [CrossRef]

66. Rihoux, B.; Ragin, C.C. Configurational Comparative Methods: Qualitative Comparative Analysis (QCA) and Related Techniques; Sage Publications: Thousand Oaks, CA, USA, 2008; pp. 17-59. 
67. Byrne, D.; Ragin, C.C. The SAGE Handbook of Case-Based Methods; Sage Publications: Thousand Oaks, CA, USA, 2009.

68. Rihoux, B. Qualitative Comparative Analysis (QCA) and Related Systematic Comparative Methods. Int. Sociol. 2016, 21, 679-706. [CrossRef]

69. Ferreira, F.A.F.; Jalali, M.S.; Ferreira, J.J.M. Integrating qualitative comparative analysis (QCA) and fuzzy cognitive maps (FCM) to enhance the selection of independent variables. J. Bus. Res. 2016, 69, 1471-1478. [CrossRef]

70. Choi, J.O.; O'Connor, J.T.; Kim, T.W. Recipes for Cost and Schedule Successes in Industrial Modular Projects: Qualitative Comparative Analysis. J. Constr. Eng. Manag. 2016, 142, 04016055. [CrossRef]

71. Seny Kan, A.K.; Adegbite, E.; El Omari, S.; Abdellatif, M. On the use of qualitative comparative analysis in management. J. Bus. Res. 2016, 69, 1458-1463. [CrossRef]

72. Schneider, C.Q.; Wagemann, C. Standards of Good Practice in Qualitative Comparative Analysis (QCA) and Fuzzy-Sets. Comp. Sociol. 2010, 9, 397-418. [CrossRef]

73. Ahuja, R.; Sawhney, A.; Arif, M. Driving lean and green project outcomes using BIM: A qualitative comparative analysis. Int. J. Sustain. Built Environ. 2017, 6, 69-80. [CrossRef]

74. Greckhamer, T.; Misangyi, V.F.; Elms, H.; Lacey, R. Using Qualitative Comparative Analysis in Strategic Management Research-An Examination of Combinations of Industry, Corporate, and Business-Unit Effects. Organ. Res. Methods 2008, 11, 695-726. [CrossRef]

75. Du, J.; Wu, H.; Zhu, L. Influencing Factors on Profit Distribution of Public Private Partnership Projects: Private Sector's Perspective. Adv. Civ. Eng. 2018, 2018, 2143173. [CrossRef]

76. Dias, A., Jr.; Ioannou, P.G. Debt capacity and optimal capital structure for privately financed infrastructure projects. J. Constr. Eng. Manag. 1995, 121, 404-414. [CrossRef]

77. Pantelias, A.; Zhang, Z. Methodological Framework for Evaluation of Financial Viability of Public-Private Partnerships: Investment Risk Approach. J. Infrastruct. Syst. 2010, 16, 241-250. [CrossRef]

78. Chen, B.; Liou, F.-M.; Huang, C.-P. Optimal Financing Mix of Financially Non-Viable Private-Participation Investment Project with Initial Subsidy. Eng. Econ. 2012, 23, 452-461. [CrossRef]

79. Chen, B.; Mao, C.-K.; Hu, J.-L. The optimal debt ratio of public-private partnership projects. Int. J. Constr. Manag. 2015, 15, 239-253. [CrossRef]

80. Thompson, C.R.; McKee, M. Financing and planning of public and private not-for-profit hospitals in the European Union. Health Policy 2004, 67, 281-291. [CrossRef] [PubMed]

81. Devapriya, K.A.K. Governance issues in financing of public-private partnership organisations in network infrastructure industries. Int. J. Proj. Manag. 2006, 24, 557-565. [CrossRef]

82. Feng, K.; Xiong, W.; Wang, S.; Wu, C.; Xue, Y. Optimizing an Equity Capital Structure Model for Public-Private Partnership Projects Involved with Public Funds. J. Constr. Eng. Manag. 2017, 143, 04017067. [CrossRef]

83. Du, J.; Han, X.; Shi, P.; Ge, J. Determine optimal capital structure for metro PPP projects to reduce financial risks: Theory and empirical analysis. In Proceedings of the 20th International Conference on Management Science \& Engineering, Harbin, China, 17-19 July 2013.

84. Iyer, K.C.; Sagheer, M. Optimization of Bid-Winning Potential and Capital Structure for Build-Operate-Transfer Road Projects in India. J. Manag. Eng. 2012, 28, 104-113. [CrossRef]

85. Singh, B.L.; Kalidindi, N.S. Criteria influencing debt financing of Indian PPP road projects: A case study. J. Financ. Manag. Property Constr. 2009, 7, 34-60. [CrossRef]

86. Li, S.; Abraham, D.; Cai, H. Infrastructure financing with project bond and credit default swap under public-private partnerships. Int. J. Proj. Manag. 2017, 35, 406-419. [CrossRef]

87. Moszoro, M. Efficient Public-Private Capital Structures. Ann. Public Coop. Econ. 2014, 85, 103-126. [CrossRef]

88. Haran, M.; McCord, M.; Hutchison, N.; McGreal, S.; Adair, A.; Berry, J.; Kashyap, A. Financial structure of PPPs deals post-GFC: An international perspective. J. Financ. Manag. Prop. Constr. 2013, 18, 184-203. [CrossRef]

89. Regan, M.; Smith, J.; Love, P.E.D. Financing of public private partnerships: Transactional evidence from Australian toll roads. Case Stud. Transp. Policy 2017, 5, 267-278. [CrossRef]

90. Zhu, M.; Wang, S.J. Study on Public-Private Partnerships Financing Structure in Hydropower Project. Adv. Mater. Res. 2012, 524, 3172-3176. [CrossRef] 
91. Regan, M.; Love, P.E.D.; Smith, J. Public-Private Partnerships: Capital Market Conditions and Alternative Finance Mechanisms for Australian Infrastructure Projects. J. Infrastruct. Syst. 2013, 19, 335-342. [CrossRef]

92. Bakatjan, S.; Arikan, M.; Tiong, R.L.K. Optimal Capital Structure Model for BOT Power Projects in Turkey. J. Constr. Eng. Manag. 2003, 129, 89-97. [CrossRef]

93. Sundararajan, S.K.; Tseng, C.-L. Managing Project Performance Risks under Uncertainty: Using a Dynamic Capital Structure Approach in Infrastructure Project Financing. J. Constr. Eng. Manag. 2017, 143, 04017046. [CrossRef]

94. Bian, Y. Decision of Capital structure in PPP projects. Guide Bus. 2016, 3, 9-10. (In Chinese) [CrossRef]

95. Chen, W. Research on the Equity Structure of A Highway PPP Project Based on Risk Sharing. Master's Thesis, Xi'an University of Architecture and Technology, Xi'an, Shaanxi, China, 2017.

96. Deng, X. The Attraction of External Funds from the PPP Projects Perspective. New Financ. 2015, 10, 43-47. (In Chinese) [CrossRef]

97. Dong, J. Equity Investment or Debt Investment? Analysis of Limited Partnership Investment Mode from the PPP Perspective. In Proceedings of the Lawyer Legal Service for One Belt and One Road-the Eighth Western Lawyer Development Conference, Lanzhou, Gansu, China, 22 September 2016. (In Chinese)

98. Du, F. Research on Strategies of Chinese Commercial Banks in PPP Projecgts. Master's Thesis, University of International Business and Economics, Beijing, China, 2015.

99. Grimsey, D.; Lewis, M.K. Are Public Private Partnerships value for money? Account. Forum 2005, 29, 345-378. [CrossRef]

100. Feng, K.; Wang, S.; Xue, Y. Optimization of PPP Project Equity Structures Based on the Satisfactions of the Main Stakeholder. J. Tsinghua Univ. (Sci. Technol.) 2017, 57, 376-381. (In Chinese) [CrossRef]

101. Guan, H. Research on the Legal Issues of Franchise in Basic Assets of Asset Securitization in PPP Projects. Contemp. Econ. 2017, 1, 96-97. (In Chinese) [CrossRef]

102. Hu, Y.; Sheng, H.; Liu, T.; Wang, S. Factors Affecting Capital Structure of PPP Projects. J. Eng. Manag. 2015, 29, 102-106. (In Chinese) [CrossRef]

103. Jiang, C.; Zhou, G. Establishment and Application of PPP Equity Shares Model Based on Cost Analysis. Price Theory Pract. 2016, 140-143. (In Chinese)

104. Jiang, J.; Tang, L. PPP-based Equity Financing Innovation. J. Dev. Oriented Financ. Res. 2015, 2, 56-61. (In Chinese) [CrossRef]

105. Li, C. The Research for the Capital Structure of Quasi-Profit Infrastructure PPP Projects. Master's Thesis, Tianjin University, Tianjin, China, 2013.

106. Li, C.; Zhang, S. Critical Factors for Capital Structure of Rail Transit PPP Projects Based on Fuzzy DEMATEL. Urban Rapid Rail Transit 2014, 27, 72-75. (In Chinese) [CrossRef]

107. Li, Y. Selection of Equity Structure Type about PPP Project Special Purpose Vehicle. Master's Thesis, Tianjin University of Technology, Tianjin, China, 2017.

108. Li, Z. Study on Financing Mode Selection and Capital Structure Design of Public-Private-Partnerships Projects in Urban Rail Transit. Master's Thesis, Beijing Jiaotong University, Beijing, China, 2017.

109. Liu, T.; Wang, S.; Sheng, H. Research on International Experiences of Capital Structure in PPP Projects. Constr. Econ. 2014, 35, 11-14. (In Chinese) [CrossRef]

110. Liu, Y. Optimal Capital Structure for Public-Private Partnership Projects' Refinance. Master's Thesis, Tsinghua University, Beijing, China, 2011.

111. Zhao, S.; Ning, Y.; Zhang, H. The Decision-Making and Application of Optimal Capital Structure Financing Scheme for Expressway PPP Project. Friends Account. 2017, 47-51. (In Chinese)

112. Na, D.; Zhang, S.; Sun, Y. Risk Analysis of Loan Bank in Financing Mode of PPP Projects. Proj. Manag. Technol. 2015, 13, 37-41. (In Chinese) [CrossRef]

113. Ye, X.; Zhang, D.; Shi, S.; Fu, X. Capital Structure Optimization of PPP Project Company from the Investment Tendency. Financ. Account. Mon. 2017, 32, 11-16. (In Chinese) [CrossRef]

114. Shen, J.; Nan, J. Equity Structure of PPP Projects. Proj. Manag. Technol. 2017, 15, 7-12. (In Chinese) [CrossRef]

115. Shen, M. Country Risks, Multilateral Financial Institutions Support and Capital Structure of PPP Project Finance-Based on "the Belt and Road" PPP Project Data. Res. Econ. Manag. 2016, 37, 3-10. (In Chinese) [CrossRef]

116. Sheng, H. Study on the Capital Structure of PPP/BOT Projects. Ph.D. Thesis, Tsinghua University, Beijing, China, 2013. 
117. Sheng, H.; Wang, S.; Huang, S. Analysis of Equity Shares of PPP Project Company and its Application in a Resthome Project. J. Eng. Manag. 2011, 25, 389-393. [CrossRef]

118. Tang, C. Optimal Equity-debt Ratio for Capital Structure Selection in PPP Projects. Rev. Econ. Res. 2017, 22, 93-98. (In Chinese) [CrossRef]

119. Shi, P. Capital Structure Optimization of Metro PPP Projects. Ph.D. Thesis, Harbin Institute of Technology, Harbin, China, 2011. (In Chinese)

120. Yang, Q. A Study on the PPP Mode and Legal Changes on Power Industry Investment Capital Structure. J. Jilin Teach. Inst. Eng. Technol. 2016, 32,1-3. (In Chinese) [CrossRef]

121. Du, J.; Xv, X. Analysis of the Application of Revenue Bond in PPP Mode. J. Eng. Manag. 2016, 30, 54-59. (In Chinese) [CrossRef]

122. Ye, X.; Zhang, Y. Risk Identification and Prevention of Commercial Bank in PPP Project Life Cycle. Constr. Econ. 2010, 10, 87-91. (In Chinese) [CrossRef]

123. Yue, Y.; Huang, X. Financing Structure Selecting Model for PPP Mode of the Government Financing Platform Existing Projects Based on FMADM. J. Hunan Norm. Univ. (Soc. Sci.) 2016, 109-115. (In Chinese)

124. Zhang, M. The Optimal Capital Structure and Its Influencing Factors of PPP Projects in New Type Urbanization-Based on General Equilibrium Perspective to Win-win Cooperation. Ind. Technol. Econ. 2017, 89-97. (In Chinese) [CrossRef]

125. Zhang, M. Source analysis of the bank loan repayment in the operation of PPP model. Econ. Res. Guide 2015, 20, 240-241. (In Chinese) [CrossRef]

126. Zhang, T.; Xv, L. Research on the Capital Structure and Compensation Model of PPP Projects. Mod. Manag. Sci. 2016, 2, 75-77. (In Chinese) [CrossRef]

127. Sun, H.; Fan, Z.; Shi, Y. Research on the Optimal Ownership Structure of an Expressway under a PPP Scheme. J. Ind. Eng./Eng. Manag. 2011, 25, 154-157. (In Chinese) [CrossRef]

128. Shen, J.; Nan, J. Study on the Equity Structure Adjustment of PPP Project Based on Markowitz Model. Friends Account. 2018, 47-51. (In Chinese)

129. Ng, S.T.; Wong, Y.M.W.; Wong, J.M.W. Factors influencing the success of PPP at feasibility stage-A tripartite comparison study in Hong Kong. Habitat Int. 2012, 36, 423-432. [CrossRef]

130. Wu, J.; Liu, J.; Jin, X.; Sing, M.C.P. Government accountability within infrastructure public-private partnerships. Int. J. Proj. Manag. 2016, 34, 1471-1478. [CrossRef]

131. Sarmento, J.M.; Renneboog, L. Anatomy of public-private partnerships: Their creation, financing and renegotiations. Int. J. Manag. Proj. Bus. 2016, 9, 94-122. [CrossRef]

132. Zhang, X. Criteria for selecting the private-sector partner in Public Private Partnerships. J. Constr. Eng. Manag. 2005, 131, 631-644. [CrossRef]

133. Ye, S. Project Finance: Theory, Practice and Cases, 2nd ed.; Beijing Jiaotong University Press: Beijing, China, 2010. (In Chinese)

134. Jain, R.; Raghuram, G.; Gangwar, R. Airport Privatization in India: Lessons from the Bidding Process in Delhi and Mumbai; Indian Institute of Management: Gujarat, India, 2007.

135. China Public Private Partnership Center. Foreign PPP Cases Selection; China Commerce and Trade Press: Beijing, China, 2014; pp. 6-10.

136. Online Database of Public Private Partnership Projects. Available online: http://www.cpppc.org:8086/ pppcentral/map/toPPPMap.do (accessed on 29 January 2018).

137. Jin, X.; Zhang, G. Modelling optimal risk allocation in PPP projects using artificial neural networks. Int. J. Proj. Manag. 2011, 29, 591-603. [CrossRef]

(C) 2018 by the authors. Licensee MDPI, Basel, Switzerland. This article is an open access article distributed under the terms and conditions of the Creative Commons Attribution (CC BY) license (http://creativecommons.org/licenses/by/4.0/). 